$\underline{\text { Research Article }}$

\title{
GREEN SYNTHESIS AND CHARACTERIZATION OF ISOLATED FLAVONOID MEDIATED COPPER NANOPARTICLES BY USING THESPESIA POPULNEA LEAF EXTRACT AND ITS EVALUATION OF ANTI-OXIDANT AND ANTI-CANCER ACTIVITY
}

\author{
MARIMUTHU GOKUL*a, UMARANI G. a, AYYAMPERUMAL ESAKKI \\ aMadurai Medical College, Madurai, Tamilnadu, India 625020, bMadras Medical College, Chennai, Tamilnadu, India 600003 \\ Email: gokulvengatnov25@gmail.com
}

Received: 27 Sep 2021 Revised and Accepted: 10 Dec 2021

\begin{abstract}
Objective: An Eco-friendly process of Green Synthesis of Copper Nano-particles (CuNPs) is an important aspect in the field of Nanotechnology using alternative feedstock, energy minimization, the design of less toxic and inherently safer chemicals.

Methods: In this study, Copper Nano-Particles were synthesized by using isolated flavonoids to induce the reduction of $\mathrm{Cu}^{2+}$ ions to CuNPs and also act as a capping and stabilizing agent. The solutions of $\mathrm{CuSO}_{4}$ and flavonoid were used as stock solutions for the preparation of CuNPs. Aqueous flavonoid (Quercetin) solution was mixed with $\mathrm{CuSO}_{4}$ solution separately. The reaction mixtures were immediately placed in a hot plate magnetic stirrer at $2000 \mathrm{rpm}, 50-60{ }^{\circ} \mathrm{C}$ temperature and observed the change in colour of the solution from colourless to coloured solution. The synthesized CuNPs were characterized by various spectral methods for structural analysis of Nano-particles and In vitro and In vivo evaluation for anti-cancer activity.
\end{abstract}

Results: The results described that the Copper Nano-particles are crystalline and amorphous with an average size of 295.4 nm and highly stable and having good hydrogen peroxide scavenging effect, reducing power and total antioxidant activity with the IC $50 \mathrm{value}$ of $59.24 \mu \mathrm{g} / \mathrm{ml}, 24.35 \mu \mathrm{g} / \mathrm{ml}$ and $16.83 \mu \mathrm{g} / \mathrm{ml}$ respectively. The in vitro (HepG2 and MCF-7 cell lines) anti-cancer activity showing good results with $\mathrm{IC}_{50}$ values of $57.56 \mu \mathrm{g} / \mathrm{ml}$ for HepG2 cell line and $56.41 \mu \mathrm{g} / \mathrm{ml}$ for MCF-7 cell line. The in vivo anti-cancer activity also showing good results.

Conclusion: Thus, this method can be used for rapid and eco-friendly biosynthesis of stable and active Copper Nano-particles.

Keywords: Antioxidant(s), Apoptosis, Cancer, Nanoparticle(s), Particle size, Spectroscopy, X-ray powder diffraction (XRD)

(C) 2022 The Authors. Published by Innovare Academic Sciences Pvt Ltd. This is an open-access article under the CC BY license (http://creativecommons.org/licenses/by/4.0/) DOI: http://dx.doi.org/10.22159/ijcr.2022v6i1.197. Journal homepage: https://ijcr.info/index.php/journal

\section{INTRODUCTION}

Nanotechnology is an enabling technology which deals with nano-meter-sized tiny objects. It is predicted that nanotechnology will be developed at various levels: materials, devices and systems. The nanomaterials level is the leading at present, both in scientific knowledge and in commercial applications [1-6].

Nano herbal drug delivery systems have a dormant future for increasing the activity and minimizing the problems associated by medicinal plants. So, the herbal nano-carriers help to treat threatening diseases like cancer, Diabetes etc. The herbal drugs can be utilized in a greater form with increased efficacy by putting together into modern dosage forms. This can be attained by designing novel drug delivery systems for herbal constituents [7].

Metal nanomaterials are known to have vast applications in the field of agriculture, energy, environment, and medicine. Metal nanomaterials are hugely biocompatible and have various pharmacological activities. Interestingly, plant-based 'Green' synthesis of nanomaterials has drawn great attention due to its cost-effective, eco-friendly, non-pathogenic, rapid, and also efficiency in the treatment process. In addition, Green synthesis provides a single-step technique as well as trouble-free to scale up for large synthesis [8-12]

The plant-based Metal Nano-particles (MNPs) showed excellent anti-microbial, anti-cancer, anti-diabetic, anti-inflammatory, antioxidant, and immuno-modulatory activities. Most of the previous reports authenticate that the presence of phytochemicals including alkaloids, flavonoids, phenols, terpenoids, alcohols, sugars and proteins in the plant materials are involved in the reduction and stabilization of metal ions. Although the synthesis of MNPs using a single active substance from plant extract will be helpful for the purification of nanoparticles, and further study on such MNPs in the biomedical sector is needed to treat specific diseases. Recent reports highlighted the fact that flavonoids widely existing in the plant extract contributing a major role in the bio-reduction of metal ionic into nanoparticle formation [13-20].

Cancer is a general term applied to a series of malignant diseases which may affects many different parts of the body. These diseases are characterized by rapid and uncontrolled formation of abnormal cells, which may mass together to form a growth or tumour, or proliferate throughout the body. Cancer is the most common cause of death throughout the world and is accountable for an estimated 9.6 million deaths in 2018. Across many countries, about 1 in 6 deaths is due to cancer. Cancer is basically a disease of cells characterized by the loss of normal cellular growth, maturation and multiplication, and thus homeostasis is disturbed [21-23].

Copper Nanoparticles are acts as Anti-cancer agent involving the process that, 1 . Accumulation of CuNPs on the cell surface from pits which causes cell leakage, 2. DNA damage due to the interaction with CuNPs, 3. Interaction of Cu ions with sulfhydral group of proteins, 4 . Entry of CuNPs and Cu ions inside the cell develops oxidative stress, which leads to cell death, 5 . Interaction of CuNPs with cell membrane decreases the transmembrane electrochemical potential, which effects membrane integrity.

The aim of the study is to synthesize, Characterise and Biological evaluation of Copper Nano Particles in which the followings are involved. 


\section{MATERIALS AND METHODS}

All the chemical reagents used in this experiment were analytical grade purchased from Lobachemie, Chennai, Tamilnadu, India. The Thespesia populnea leaves were collected at $10^{\circ} 20^{\prime} 02.0^{\prime \prime} \mathrm{N} 79^{\circ} 11^{\prime} 37.8^{\prime \prime E}$ Kalathur, Pattukkottai(Tk), Thanjavur(Dt), Tamilnadu, India on 19.08 .2018 and was authenticated by Dr. Stephen, Professor, Department of Botany, American college, Madurai-625 020 on 20.08.2018. The leaves were collected and shade dried. It was powdered and the coarse powder was sieved and stored in a well-closed container.

\section{Green synthesis of copper nanoparticles by using flavonoid quercetin as a stabilizing agent}

Double distilled water has been used throughout the synthesis process. $1 \mathrm{mmol}$ solutions of $\mathrm{CuSO}_{4}$ and $0.02 \%$ flavonoid were used as stock solutions for the preparation of CuNPs. The flavonoid (Quercetin) was dissolved in water by slightly increasing the $\mathrm{pH}$ using $\mathrm{NaOH}$ as they are sparingly soluble in water. After complete dissolution of flavonoid, the $\mathrm{pH}$ was neutralized using $\mathrm{HCl} .10 \mathrm{ml}$ of aqueous flavonoid (Quercetin) solution was mixed with $90 \mathrm{ml}$ of $1 \mathrm{mmol} \mathrm{CuSO}_{4}$ solution separately. The reaction mixtures were immediately placed in a hot plate magnetic stirrer at $2000 \mathrm{rpm}$, at $50-60{ }^{\circ} \mathrm{C}$ temperature and observed for change in colour of the solution. After $60 \mathrm{~min}$, the resulting solution was turned out from light green to dark brown colour indicating the formation of copper nanoparticles. After the incubation, the solution was centrifuged at $12,000 \mathrm{rpm}$ for $25 \mathrm{~min}$. The pellet was resuspended in distilled water and stored in the freezer for further study [24-26].

\section{Characterization of synthesized CuNPs}

\section{UV-visible spectrum}

UV-visible absorbance spectroscopy has been proved to be a significant technique for the detection of synthesized metallic NPs because the peak position and shape of the spectra are sensitive to the particle size. The reduction of pure $\mathrm{Cu}$ to Copper Nanoparticle was observed by measuring the UV-Vis spectrum, the most confirmatory tool for the detection of Surface Plasmon Resonance property (SPR) of CuNPs. UV-Vis spectral analysis was done by using a UV-Vis spectrophotometer (SHIMADZU) at a range 400 to $700 \mathrm{~nm}$ [27-31].

\section{FT-IR spectrophotometer}

The characterization of functional groups at the surface of $\mathrm{Cu}$ nanoparticles by flavonoid(Quercetin) were investigated by FTIR analysis and the spectra were scanned in the range of $4000-450 \mathrm{~cm}^{-1}$. The sample was prepared by dispersing the CuNPs uniformly in a matrix of dry $\mathrm{KBr}$, compressed to form an almost transparent disc. This technique is used to acquire an infrared spectrum of absorption, emission, photoconductivity or Raman scattering of a solid, liquid and gas [27-31].

\section{Atomic absorption spectrometry}

Atomic Absorption Spectroscopy (AAS) is a technique of quantitative determination of chemical elements by using the absorption of optical radiations by free atoms in the gaseous state. The metal content was determined by flame atomic absorption spectroscopy equipped with a hollow cathode lamp and an air-acetylene flame (Analytik Jena AG, nova A 350, Jena, Germany). The wavelengths (nm) used for the determination of the various metals were: Copper 324.8, Nickel 232.0, Cadmium 228.8 and Lead 283.3. Gas flow was 15 (L/min) and Element: Cu Atomizer/Gas Flow Rate: Setup Fuel Gas Flow Rate (L/min): 1.8, Support Gas Flow Rate (L/min): 15.0 [27-31].

\section{Particle size distribution and polydispersity index}

Average particle size, particle size distribution and Polydispersity index were measured by MALVERN ZETASIZER instrument. Stability and particle size distribution were measured by standard values such as,

$>$ D (0.9) corresponds to particle size immediately above $90 \%$ of the sample

$>\mathrm{D}(0.5)$ corresponds to particle size immediately above $50 \%$ of the sample

$>\mathrm{D}(0.1)$ corresponds to particle size immediately above $10 \%$ of the sample.

\section{ZETA potential}

Zeta potential is an electrical potential which is exhibited by any particulate matter in suspension. If all the particles within the suspension having large zeta potential values (positive or negative) they have a tendency to repel one another and there will be no tendency for the particles to come together. However, if the particles have low zeta potential values, then there will be no force to prevent the particles to come together and being flocculated.

The zeta potential value can be related to the stability of colloidal system. A value of $+25 \mathrm{mV}$ to- $25 \mathrm{mV}$ can be taken as an arbitrary value that separates low charged surface from a high charged surface. Zeta potential was analyzed by MALVERN ZETASIZER instrument [27-31].

\section{X-ray diffraction (XRD)}

The CuNPs solution was centrifuged, re-dispersed with distilled water and lyophilized to obtain pure CuNPs and CuNPs Pellets. The XRD analysis was done with X-ray diffractometer at a scanning speed of $0.15^{\circ}$ per min from $10-100^{\circ}$ (2Ө degree). XRD pattern is characterized by the interplanar $\mathrm{d}$-spacing and the relative intensities $\left(\mathrm{I} / \mathrm{I}_{0}\right)$ of the strongest peaks in the pattern under the Hanawalt system. It was acknowledged the position of values of product crystallinity or amorphic nature [27-31].

\section{Scanning electron microscopy (SEM)}

Scanning Electron Microscope using a focused beam of electrons, it generates various signals at the surface of a solid sample which reveals the details of surface morphology, chemical composition, crystalline structure and therefore, the orientation of materials constituting the sample. For visualizing FMCuNPs under SEM $10 \mu \mathrm{l}$ was uniformly spread on a glass slide and allowed to dry at room temperature. After gold coating the sample with a Polaron E5100 gold sputter coater, the morphology was observed under a Philips 505 electron microscope at an accelerating voltage of 20 $\mathrm{kV}$. SEM image of flavonoid (Quercetin) mediated biosynthesized copper nanoparticles indicated the formation of homogeneous and relative capping of spherical CuNPs [27-31].

\section{Energy-dispersive X-ray spectroscopy (EDXS)}

Energy Dispersive X-ray Spectroscopy (EDXS) is a semi-quantitative X-ray micro-analytical technique that can come up with information about the elemental composition of a sample. It is useful in identifying metals and certain kinds of polymeric materials with distinctive elemental signatures. During EDXS Analysis, an electron beam is scanned over the surface of the sample and therefore the electrons strike and stimulates the sample. 
Almost instantaneously, as each element returns to its original energy level, it emits X-rays of specific energies and at different wavelengths characteristic of the element [27-31].

\section{Swiss target prediction of isolated quercetin}

Swiss Target Prediction is based on the study that indistinguishable bioactive molecules are more probably to share similar targets. It is an online server to exactly predict the targets of bioactive molecules based on a mixture of 2D and 3D similarity measures with known ligands [32].

\section{Pharmacological evaluations of synthesized FMCuNPs}

\section{Anti-oxidant activity}

The Anti-oxidant activity of FMCuNPs was performed by the following methods,

\section{Determination of scavenging activity against hydrogen peroxide}

The test was done with the help of UV-Vis Spectrophotometer Shimadzu (Model 1800). To 1 ml of test solutions of different concentrations, 3.8 ml of $0.1 \mathrm{M}$ phosphate buffer solution ( $\mathrm{pH} 7.4$ ) and then $0.2 \mathrm{ml}$ of hydrogen peroxide solution were added. The absorbance of the reaction mixture was measured at $230 \mathrm{~nm}$ after $10 \mathrm{~min}$. The reaction mixture without the sample was used as blank and Ascorbic acid was used as standard. The percentage inhibition of hydrogen peroxide was calculated applying the formula,

$$
\% \text { inhibition }=[(\text { Control-Test }) / \text { Control }] \times 100
$$

The concentration of the sample required for $50 \%$ reduction in absorbance $\left(\mathrm{IC}_{50}\right)$ was calculated using linear regression analysis [33-35].

\section{Determination of reducing power assay}

The reducing power ability of CuNPs was screened by assessing the ability of the test extract to reduce $\mathrm{FeCl}_{3}$ solution as mentioned by Oyaizu et al., (1986). 0.1 to $0.5 \mathrm{ml}$ of sample solution $(1 \mathrm{mg} / \mathrm{ml}$ ) was mixed with $0.75 \mathrm{ml}$ of phosphate buffer and $0.75 \mathrm{ml}$ of $1 \%$ Potassium Ferricyanide $\left[\mathrm{K}_{3} \mathrm{Fe}\left(\mathrm{CN}_{6}\right)\right]$ and incubated at $50{ }^{\circ} \mathrm{C}$ for $20 \mathrm{~min}$. About $0.75 \mathrm{ml}$ of $10 \%$ Trichloroacetic acid was added to the mixture and allowed to stand for 10 min. The whole mixture was then centrifuged at $3000 \mathrm{rpm}$ for $10 \mathrm{~min}$. Finally, $1.5 \mathrm{ml}$ of the supernatant was removed and mixed with $1.5 \mathrm{ml}$ of distilled water and $0.1 \mathrm{ml}$ of $0.1 \%$ Ferric Chloride solution and the absorbance was measured at $700 \mathrm{~nm}$ in UV-Visible Spectrophotometer. Ascorbic acid solution was used as standard and phosphate buffer solution was used as blank solution [33-35].

\section{Determination of total antioxidant activity}

The total antioxidant activity of the CuNPs was evaluated by Phospho molybdenum method using UV-Visible spectrophotometer, Shimadzu (Model) 1800. An aliquot of $0.3 \mathrm{ml}$ of various concentrations of the sample was treated with 2.7 ml of the reagent $\mathrm{H}_{2} \mathrm{SO}_{4}$, sodium orthophosphate and ammonium molybdate). Just in case of blank, $0.3 \mathrm{ml}$ of methanol was utilized in place of the sample. The sample tubes were incubated in a boiling water bath at $95{ }^{\circ} \mathrm{C}$ for about $90 \mathrm{~min}$. The samples were adjusted to room temperature by cooling; the absorbance of each and every concentration of the aqueous solution was measured at $695 \mathrm{~nm}$ against blank. Similarly, Vitamin C standard was treated. The antioxidant activity was expressed as an equivalent of vitamin $\mathrm{C}(\mu \mathrm{g} / \mathrm{ml})$ [33-35].

\section{In vitro anticancer activity}

\section{MTT assay by using liver cancer cell line (HepG5) and breast cancer cell line (MCF-7)}

The MTT (3-(4, 5-dimethylthiazolyl-2)-2, 5-diphenyltetrazolium bromide) assay, based on the conversion of the yellow Tetrazolium salt-MTT, to purple-Formazan crystals by metabolically active cells, provides a quantitative determination of viable cells. HepG5, MCF-7 Cells are plated on to 96 well plates at a cell density of $2 \times 105 \mathrm{ml}^{-1}$ per well in $100 \mu \mathrm{L}$ of RPMI 1640 and allowed to grow in $\mathrm{CO}_{2}$ incubator for $24 \mathrm{~h}(37 \mathrm{C}, 5 \% \mathrm{CO} 2)$. Then the medium is replaced by a fresh medium containing various concentrations of samples (FMCuNP's) for $24 \mathrm{~h}$. The cells are incubated for $24-48 \mathrm{~h}\left(37^{\circ} \mathrm{C}\right.$, $\left.5 \% \mathrm{CO}_{2}\right)$. Then, $20 \mu \mathrm{L}$ MTT stock solution $(0.5 \mathrm{mg} / \mathrm{ml})$ was added to each well and incubated for $4 \mathrm{~h}$. The medium is removed and $200 \mu \mathrm{L}$ DMSO (Dimethyl Sulfoxide) is added to each well to dissolve the MTT metabolic product. Then the plate is shaken at 150 rpm for 5 min and the optical density is measured at $570 \mathrm{~nm}$. Untreated cells (basal) are used as a control of viability (100\%) and the results are expressed as \% viability (log) relative to the control [36-38].

$$
\text { Cytotoxicity }(\%)=[(\mathrm{A}-\mathrm{B}) / \mathrm{A}] \mathrm{X} 100
$$

Where,

$A=$ Absorbance of the untreated group

$\mathrm{B}=$ Absorbance of treated group

\section{In vivo anticancer activity}

In the present work, cell lines induced cancer in mice was used to evaluate the anticancer activity. Swiss albino mice and Dalton's Lymphoma Ascites (DLA) cell was approved and supplied by Research Advisory Council and Institutional Animal Ethical Committee, Amala Cancer Research Center, Trissur, Kerala, India. The cells were maintained alive in Swiss albino mice by intraperitoneal transplantation. While transferring the tumour cells to the grouped animal, the DLA cells were aspirated from the greater peritoneal sac of the mice using saline. The cell counts were done and further dilution were made in such a manner that total cells should be $1 \times 106$, this dilution was given intraperitoneally. Let the tumour grow within the mice for minimum of seven days before starting treatments [35-42].

\section{Treatment protocol}

Swiss Albino mice were divided in to four groups of six each. All the animals in three groups were injected with DLA cells ( 1 x 106 cells per mouse) intraperitoneally, and the remaining one group is the normal control group.

Group 1 served as the normal control.

Group 2 served as the tumour control. Group 1 and group 2 received normal diet and Water.

Group 3 served as the positive control, was treated with Fluorouracil (inj.) at $20 \mathrm{mg} / \mathrm{kg}$ body weight, Intraperitoneal. 
Group 4 served as a treatment control group and received Quercetin mediated Copper nanoparticles of at a dose of 10 mg/kg through intraperitonealy.

\section{Treatment}

In this current study, drug treatment was given once daily for $14 \mathrm{~d}$ after $24 \mathrm{~h}$ of inoculation. On 14 th day, after the last dose, all mice from every group were sacrificed and the blood was withdrawn from each mouse by retro-orbital plexus method and the following parameters were checked.

\section{Evaluation of clinical parameters}

\section{1) Haematological parameters}

\section{i) WBC count}

The total WBC count was found to be increased in cancer control when compared with normal and treated tumor-bearing mice. The total WBC counts were found to decrease significantly in animals treated with extract when compared with cancer control, indicating that the anti-tumour nature of the extract.

\section{ii) RBC count}

RBC count decreases with tumour bearing mice when compared with Normal control mice.

\section{iii) Platelet count}

In Hodgkin lymphoma, increased in platelet count is often reported in laboratory findings.

\section{iv) Haemoglobin count}

Haemoglobin count decreases with tumour bearing mice when compared with Normal control mice.

\section{iv) Packed cell volume}

In any case of anaemia the packed cell volume decreases.

\section{2) Serum enzyme and lipid profile}

\section{i) Total cholesterol and triglyceride (lipid profile)}

Abnormal blood lipid profile has been correlated with cancer. In Hodgkin lymphoma, high level of cholesterol and low level of triglyceride has been reported.

\section{ii) Liver enzymes (AST, ALT, ALP)}

Abnormal liver function noticed in a patient with Hodgkin lymphoma, that these liver enzyme levels markedly increases in tumor bearing mice. ALP is an enzyme mostly derived from the liver, bones and in lesser amount from the intestines, placenta, kidneys and leukocytes. An increase in ALP levels in the serum is normally associated with various diseases. ALP is composed of a group of enzyme that catalyzes the phosphate esters in an alkaline environment, generating an organic radical and inorganic phosphate. Notably elevated serum ALP, hyper alkaline-phosphataemia, is seen primarily with more specific disorders; including malignant biliary cirrhosis, hepatic lymphoma and sarcoidosis.

\section{3) Derived parameters}

\section{Bodyweight}

All the mice were weighed from the starting day to 15th day of the study. Average increase in weight of the body on the 15th day was determined.

\section{Percentage increase in life span (ILS)}

\% ILS was calculated by means of the formula,

\%ILS = (Lifespan of treated group/lifespan of the control group) $-1 \times 100$

$>$ All biochemical investigations were carried out by using COBAS MIRA PLUS-S Auto analyzer from Roche Switzerland.

$>$ Hematological tests were executed in COBAS MICROS OT 18 from Roche Switzerland.

\section{Cancer cell count}

About $0.1 \mathrm{ml}$ of fluid was withdrawn from the peritoneal sac of each and every mouse with the help of sterile syringe. The fluid was diluted with 0.8 $\mathrm{ml}$ of ice-cold normal saline or sterile Phosphate Buffer solution and $0.1 \mathrm{ml}$ of Trypan blue $(0.1 \mathrm{mg} / \mathrm{ml})$. The total numbers of the living cells were counted using haemocytometer.

$$
\text { Cell count }=\text { No of cells Dilution } /(\text { Area } \times \text { Thickness of liquid film) }
$$

\section{Effect of FMCuNPs on survival time}

Animals were divided into four groups; six animals each in a group. Except the normal control group, the remaining groups were inoculated with DLA cells (1x106 cells/mouse) intraperitonealy on day ' 0 ' and treatment with FMCuNPs started $24 \mathrm{~h}$ after inoculation, at a dose of 200 mg/kg/day. The normal and tumor control group was treated with the same volume of $0.9 \%$ Sodium Chloride solution. All the treatments were given to animals for the duration of $14 \mathrm{~d}$. The increase in life span (ILS) of each groups of 6 mice was noted. The anti-tumor efficacy of FMCuNPs was compared with that of 5-Fluorouracil (Dabur pharmaceutical ltd. India; 5-FU, $20 \mathrm{mg} / \mathrm{kg} /$ day, i. p for $14 \mathrm{~d}$ ). The ILS of the drug-treated groups was compared with that of the control group using the following formula:

$$
\text { Increase in lifespan }=[(\mathrm{T}-\mathrm{C}) / \mathrm{C}] \times 100
$$

Where $\mathrm{T}=$ number of days that the treated animal survived.

$\mathrm{C}=$ number of days that the control animals survived. 


\section{RESULTS AND DISCUSSION}

Green synthesis of nanoparticles using plants as bio-reductants have more advantages than other biological processes because here no need to maintain the cell culture and also suitable for large scale synthesis.

\section{Green synthesis of flavonoid mediated Cu nanoparticles with thespesia populnea (L.) leaf extract}

Quercetin, a plant flavonoid found in fruits, vegetables and grains which is reported to have an inflammatory and antioxidant property. It is also beneficial in the treatment of allergy and blood pressure. In this present study, we have isolated the Quercetin from the aqueous extract of Thespesia populnea leaves. The active Quercetin was used as a reactant to nucleate nanoparticles in solution. Initially, the confirmation of the formation of CuNPs was done through monitoring the change in colour of the reaction mixture with concomitant UV-Visible spectroscopy. Addition of optimal volume of $\mathrm{CuSO}_{4}$ has changed the colour of the solution from light green to dark brown colour validating the formation of CuNPs (fig. 1).

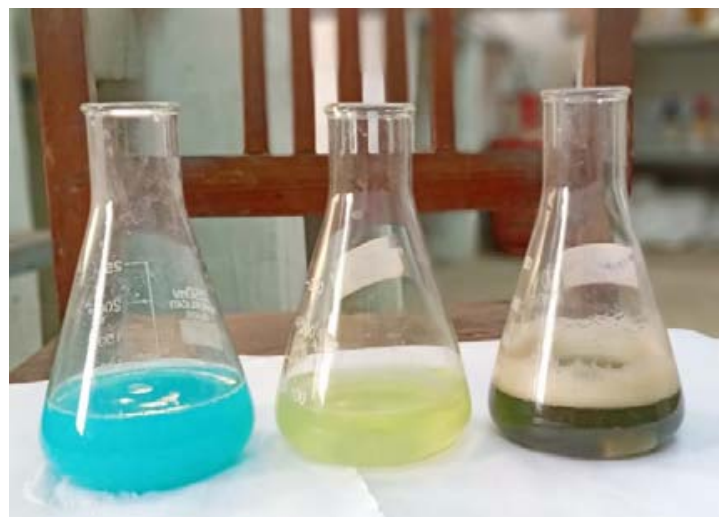

Fig. 1: Observation of color changes during synthesis of copper nanoparticles at different time

The Flavonoid, Quercetin which can reduce metal ions to metal NPs shown in fig. 2.

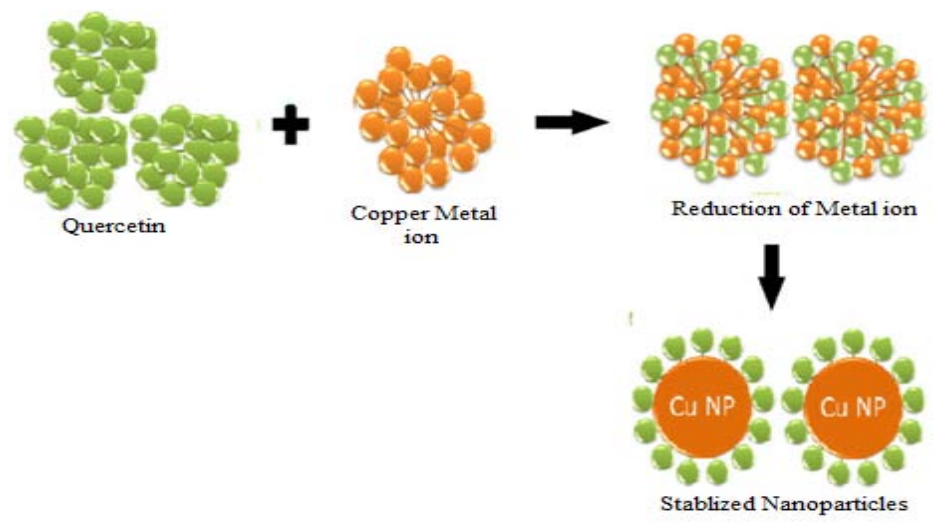

Fig. 2: Flavonoid quercetin responsible for the bio-reduction of metal ions

The possible equation for the synthesis of CuNPs is mentioned in fig. 3.

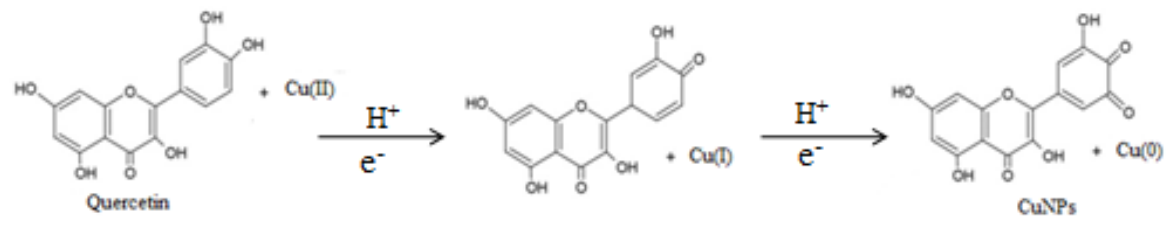

Fig. 3: Synthetic reaction process for flavonoid mediated copper nanoparticles

\section{UV-Vis spectrophotometry}

Next the synthesized Copper nanoparticles (CuNPs) were characterized by UV-Vis spectroscopy. The UV-Visible spectrum of the CuNPs solution was recorded at different time intervals $(1,3,6,12$ and $24 \mathrm{~h})$ (fig. 4). The appearance of a sharp and high peak at $620 \mathrm{~nm}$ in the spectrum indicates the 
stability and size of the Copper nanoparticles. Enhanced absorbance implies the reduction of $\mathrm{Cu}^{++}$to $\mathrm{Cu}$ as the formation of nanoparticles results in concomitant accumulation of CuNPs.

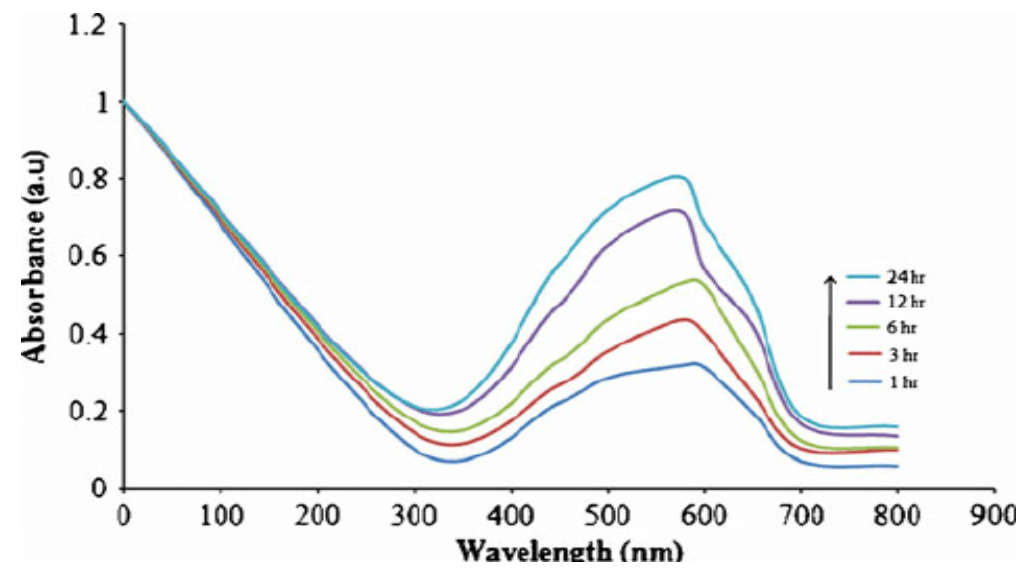

Fig. 4: UV-visible spectrum of FMCuNPs at different time interval during the synthetic process

\section{IR-spectrum of FMCuNPS}

After confirming the formation of Copper nanoparticles, we assayed their stability by FTIR spectra of bio-reduced CuNPs (fig. 5). Major peaks at $3338.78 \mathrm{~cm}^{-1}$ (O-H stretching of phenolic group), $1618.28 \mathrm{~cm}^{-1}$ ( $\mathrm{C}=\mathrm{O}$ stretching), and $1095.57 \mathrm{~cm}^{-1}$ (C-O-C stretching), were detected suggesting the presence of Quercetin in CuNPs.

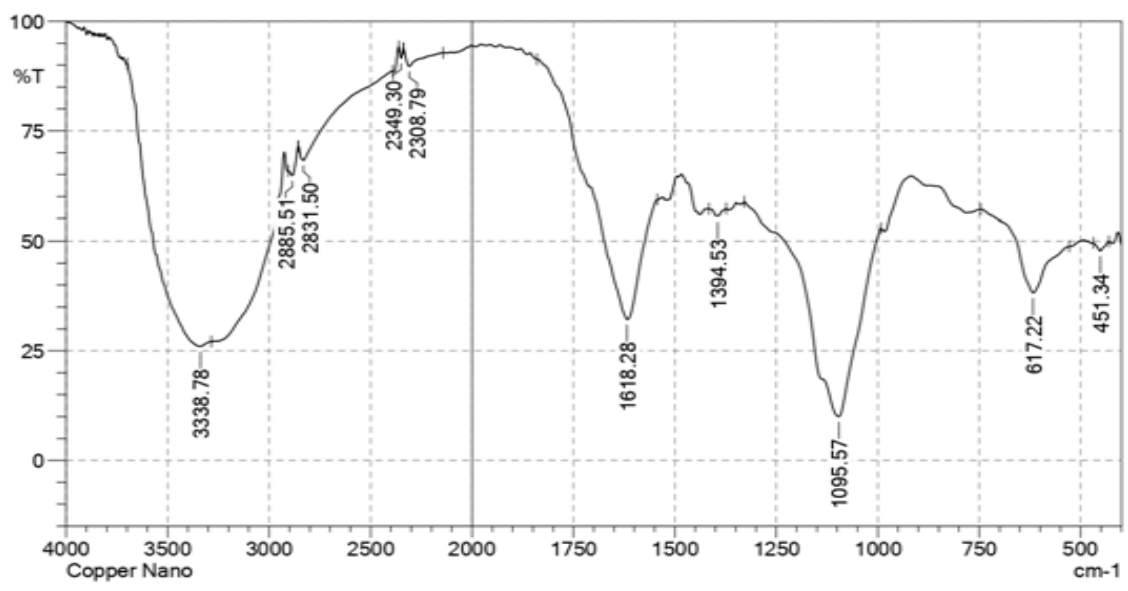

Fig. 5: FTIR spectra of synthesized CuNPs

\section{Atomic absorption spectroscopy}

Next, we have analysed the sample by atomic absorption spectroscopy at $320 \mathrm{~nm}$. The absorbance of Copper nanoparticles present in the sample was (fig. 7) compared with the standard calibration graph (fig. 6). Comparative data reveals that the tested sample has the same concentration as that of standard one and it lies within the permissible range $(10 \mathrm{ppm})$. It also obeys the Beer-Lambert's laws.

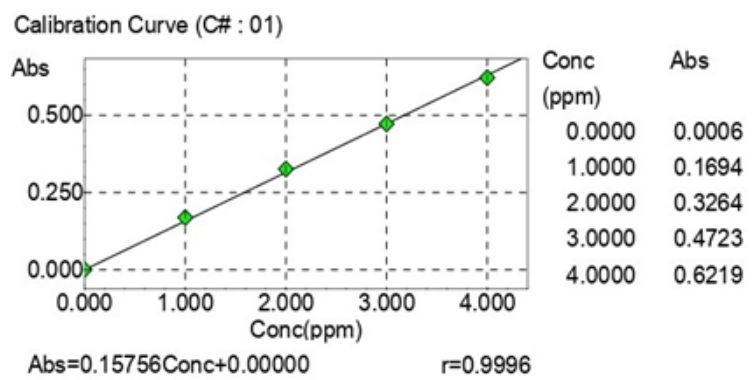

Fig. 6: Calibration curve of copper 
a

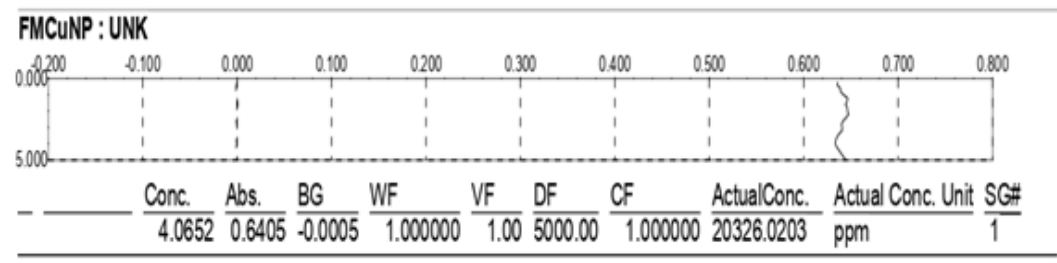

Fig. 7: Atomic absorption spectrum of FMCuNPs

\section{Particle size distribution and polydispersity index}

We have verified the identity of the synthesized nanoparticles by measuring the particle size and polydispersity index of the sample by DLS study. Our data shows that the zeta potential, polydispertive index and particle size of FMCuNPs are 23.5, 0.213 and $295.4 \mathrm{~nm}$, respectively (fig. 8). Hence we can decipher that FMCuNPs are nano-sized particles and stable in manner.

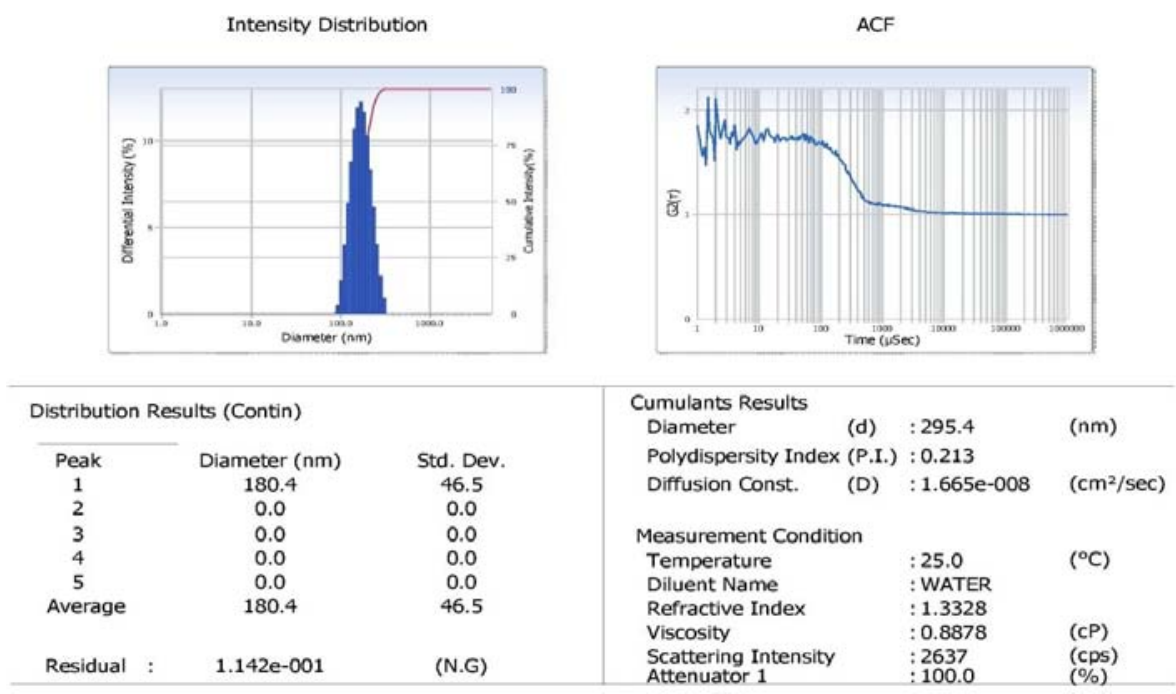

Fig. 8: Particle size and polydispersitive index of FMCuNPs

\section{Zeta potential analysis}

Further to elucidate the surface property of the synthesized nanoparticles, we have performed Zeta Potential Analysis. Zeta Potential of the synthesized nanoparticles was found to lie within the desired mille volt range $(-30 \mathrm{mV}$ to $+30 \mathrm{mV})$. The higher charge on the surface of FMCuNPs acts as a repulsive force between the FMCuNPs which made them stable and devoid of agglomeration (fig. 9). Thus, Zeta Potential Analysis has reconfirmed the stability of the synthesised FMCuNPs.

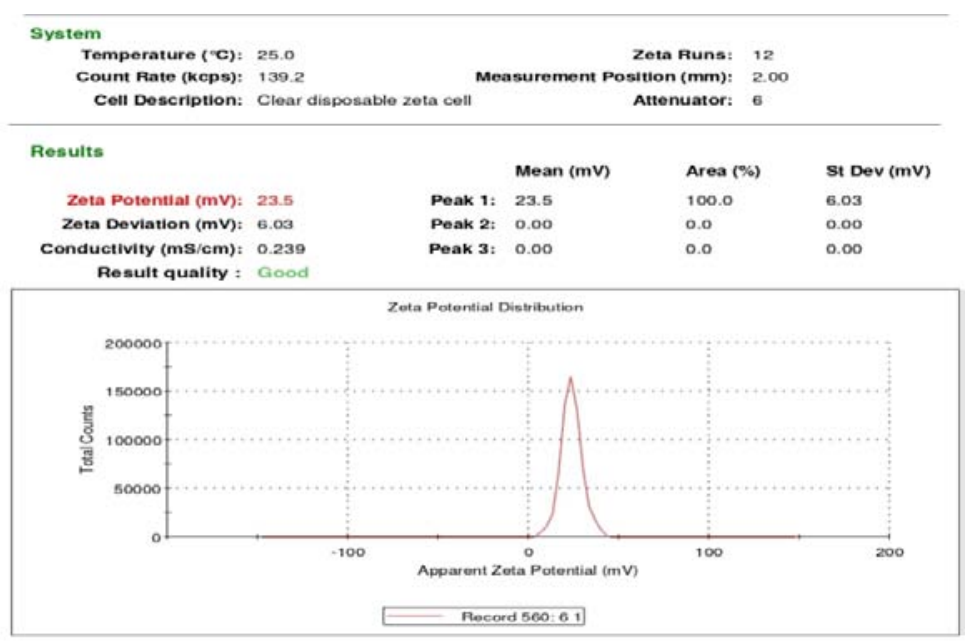

Fig. 9: Zeta potential graph of FMCuNPs 


\section{X-ray diffraction analysis of FMCuNPs}

Next, XRD analysis of FMCuNPs has been done to quantify the relative occurrence of the crystalline and amorphous structured species in the nanoparticle sample. Fig. 10 depicts a typical XRD profile of synthesized FMCuNPs with diffraction peaks at $2 \mathrm{hr}$ of $25.38^{\circ}, 26.57^{\circ}, 15.3^{\circ}, 31.49^{\circ}$, and

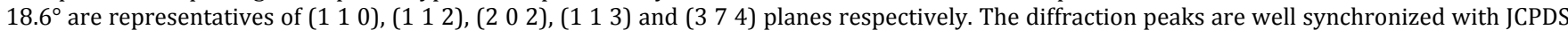
Card (Joint Committee on Powder Diffraction Standards, 89-2529) and thus, we can interpret that 20.3\% of the green synthesised FMCuNPs are present in crystalline nature and the remaining $79.7 \%$ have acquired an amorphous appearance. The calculated average crystallite size of green synthesized FMCuNPs was found to be in the range of $20-100 \mathrm{~nm}$.

\section{Sir.C.V. RAMAN KRISHNAN}

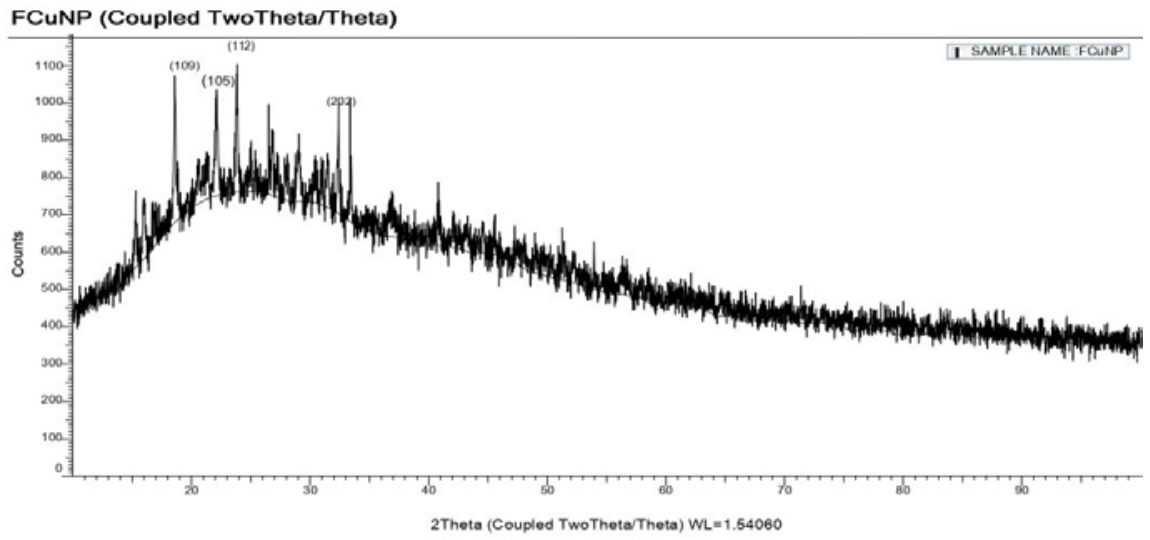

Fig. 10: X-ray diffraction spectrum of greenly synthesized FMCuNPs

\section{Scanning electron microscopy (SEM) analysis}

The morphological characteristics of green synthesized FMCuNPs were examined by Field Emission Gun-Scanning Electron Microscopy (FE-SEM). Fig. 11 displays the electro micrograph of the green synthesised FMCuNPs depicting their morphology features. FMCuNPs appears like agglomerated spherical shaped entity and are dispersed as clusters. The size of particles is considerably small and falls in the range of 20-300 nm, further strengthening the data obtained from the XRD spectrum (fig. 10).
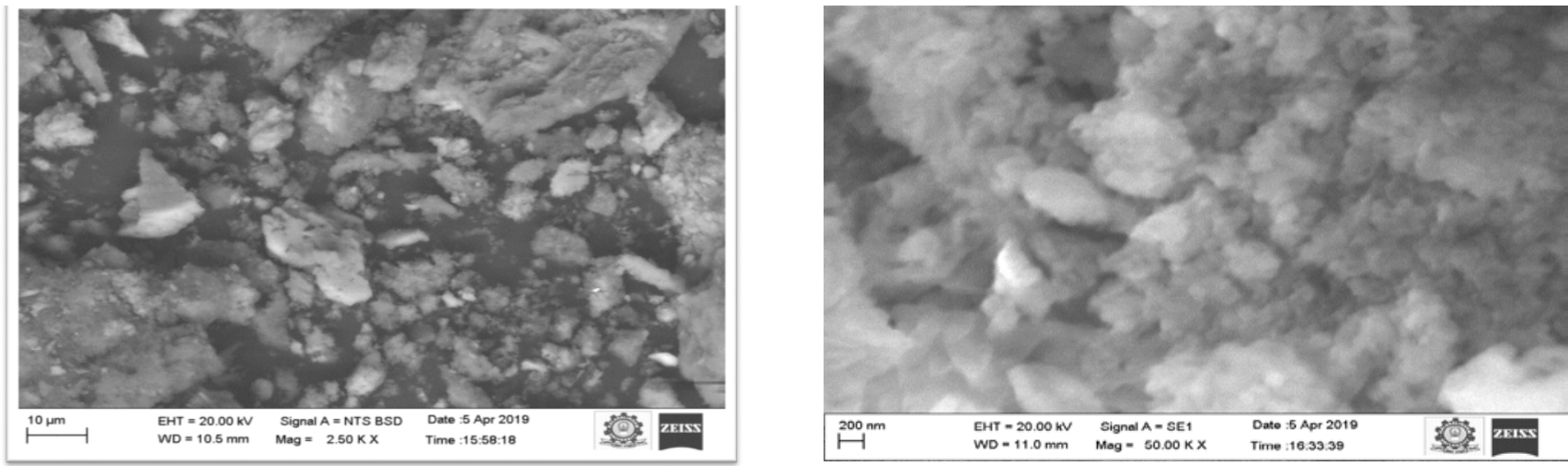

Fig. 11: SEM image of greenly synthesized FMCuNPs at $10 \mathrm{~nm}$ and $200 \mathrm{~nm}$ in size range

\section{Energy-dispersive X-ray spectroscopy (EDAX)}

The chemical composition of green synthesized FMCuNPs has been studied by the EDAX analysis (Fig.12). Our data has revealed the chemical composition of green synthesized nanoparticles containing the elements in atomic percent $12.6 \%$ of $\mathrm{Cu}, 46.0 \%$ of $\mathrm{C}$ and $41.8 \% \mathrm{O}$. EDAX results confirmed that green synthesized FMCuNPs are uncontaminated pure materials containing only copper and flavonoid related atoms. 


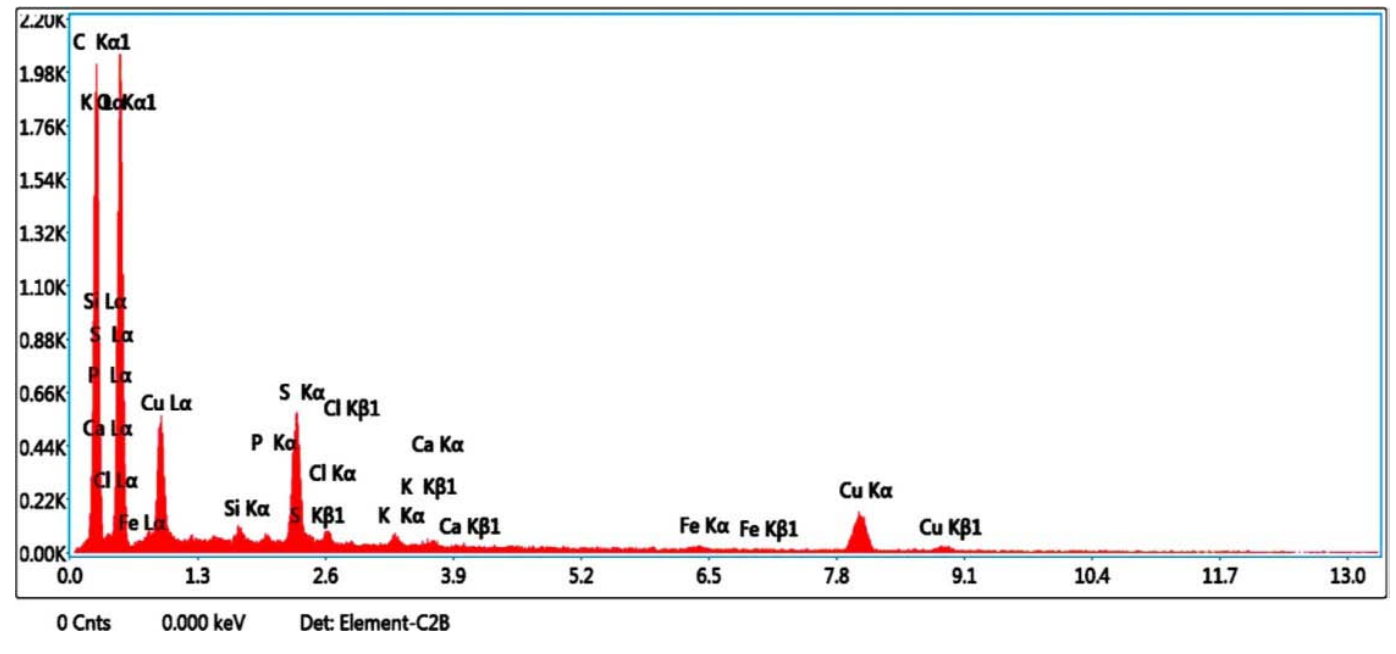

Fig. 12: EDAX spectrum of greenly synthesized FMCuNPs

\section{Swiss target prediction of isolated quercetin structure}

Next, we have used the "Swiss target prediction," an online tool for exploring the probable macromolecular target of our synthesized nanoparticles. This analysis has verified that the isolated Quercetin may have affinity against various cellular receptors. According to the Swiss Target Prediction report of Quercetin (fig. 13), receptors associated with cellular proliferation and potential redox maintenance like epidermal growth factor receptor, Tyrosine kinase receptor are probable primary target of Quercetin.

\section{SwissTargetPrediction report:}
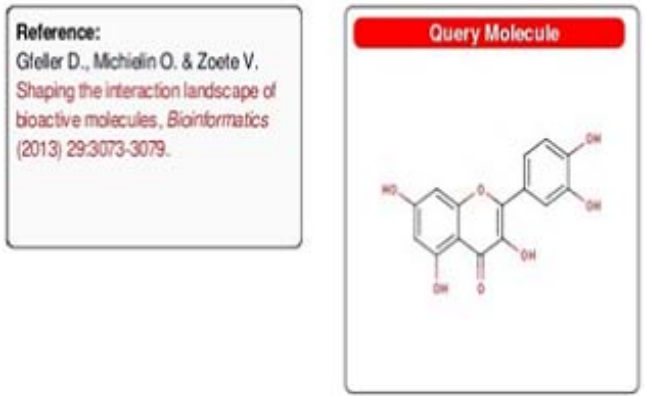

\begin{tabular}{|c|c|c|c|c|c|c|}
\hline Target & $\begin{array}{l}\text { Uniprot } \\
\text { ID }\end{array}$ & $\begin{array}{l}\text { Gene } \\
\text { code }\end{array}$ & ChEMBL id & Probablity & $\begin{array}{c}\text { Isim } \\
\text { cmpds (30 } \\
\text { (2D) }\end{array}$ & Target Class \\
\hline Carbonic anhydrase 12 & $0<9570$ & CA12 & CHEMBL3242 & & $3 / 5$ & Enzyme \\
\hline Epidermal growth factor receptor & Poosso & EOF & CHENBL203 & & $6 / 28$ & Tyr Kinase \\
\hline Carbonic antydrase 1 & Poopt5 & as & CHENBL261 & & $10 / 7$ & Enzyme \\
\hline Cartonic antydrase 2 & Poovis & $\omega_{2}$ & CHENBL205 & & $10 / 7$ & Enzyme \\
\hline Phospholpase A2 & Pousst & Puegrs & CHEMBL4A26 & & $1 / 1$ & Enzyme \\
\hline $\begin{array}{l}\text { Receptor tyrosine protein kinase } \\
\text { erbB-2 (by homology) }\end{array}$ & P04626 & EPso: & CHEMBL182 4 & & $6 / 28$ & TyrKinase \\
\hline Myeioperoxidase & Posise & wo & CHEMBL2439 & & $1 / 1$ & Enzyme \\
\hline $\begin{array}{l}\text { Cylochrome P450 1A2 (by } \\
\text { homology) }\end{array}$ & posint & CTPLI2 & CHEMBL3356 & & $8 / 13$ & Enzyme \\
\hline Cyclindependert kinase 1 & posess & $\cos t$ & CHENBL 308 & & $3 / 27$ & Ser_Thr Kinase \\
\hline Carbonic arhydrase 3 & Po7 45: & w & CHEMBL2885 & & $10 / 7$ & Enzyme \\
\hline Alphatrypsinchain 1 & PO747 & pQss: & CHEMBL209 & & $1 / 2$ & Serne Protease \\
\hline PEX & pouss & wer & CHENBL 333 & & $5 / 2$ & Metalo Protease \\
\hline Stromeysin-1 & poezse & wes & CHENEL283 & & $3 / 2$ & Metalo Proteose \\
\hline Arachidonate 5 -lporygenase & POQW17 & Noss & CHENBLL215 & & $10 / 52$ & Enzyme \\
\hline Mcrotubule-associated protein tau & P10t36 & wart & CHEMBL1293224 & & $25 / 77$ & Unclassiffed \\
\hline
\end{tabular}

Fig. 12: Swiss target prediction of isolated quercetin 


\section{Pharmacological evaluations of synthesized FMCuNPs}

In order to assay the anti-cancerous potential of the FMCuNPs, we have furthered our study by subjecting the green synthesized FMCuNPs to In vitro anti-oxidant studies. It includes hydrogen peroxide scavenging activity, total antioxidant capacity and reducing power assay.

\section{Determination of hydrogen peroxide scavenging activity of greenly synthesized FMCuNPs}

The inhibitory concentration ( $\mathrm{IC}_{50}$ ) for the hydrogen peroxide scavenging effect of greenly synthesized FMCuNPs (fig. 14 and table 1 ) is found to be $59.24 \mu \mathrm{g} / \mathrm{ml}$ whereas ascorbic acid a potent standard antioxidant exhibit the $\mathrm{IC}_{50}$ value to be $60.15 \mu \mathrm{g} / \mathrm{ml}$.

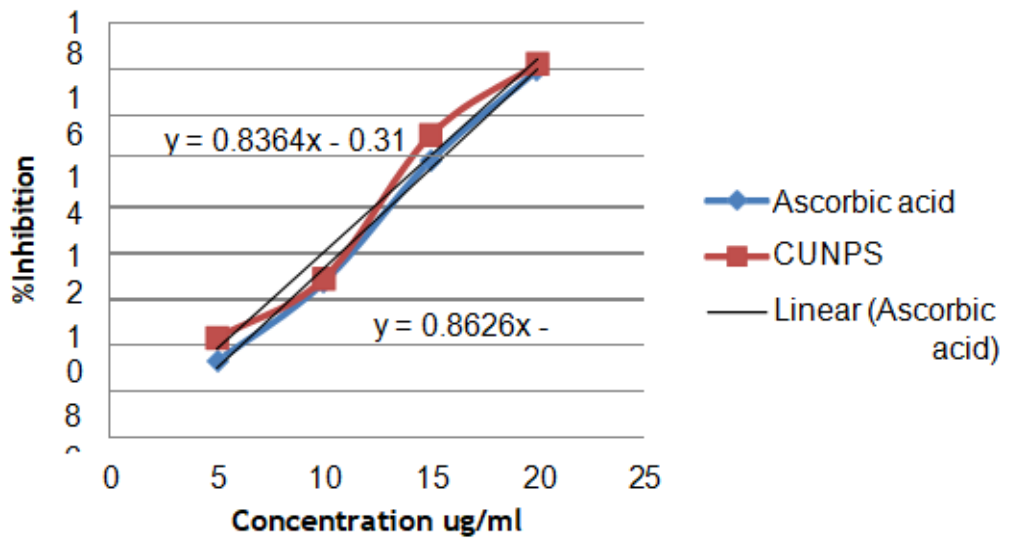

Fig. 14: Hydrogen peroxide scavenging effect by ascorbic acid

Table 1: Determination of hydrogen peroxide scavenging activity of greenly synthesized FMCuNPs

\begin{tabular}{llll}
\hline $\begin{array}{l}\text { S. No. } \\
\end{array}$ & $\begin{array}{l}\text { Concentration of } \\
\text { ascorbic acid }(\boldsymbol{\mu g} / \mathbf{m l})\end{array}$ & $\begin{array}{l}\text { Percentage inhibition of } \\
\text { ascorbic acid standard }(\boldsymbol{\mu g} / \mathbf{m l})\end{array}$ & $\begin{array}{l}\text { Concentration of greenly } \\
\text { synthesized FMCuNPs }(\boldsymbol{\mu g} / \mathbf{m l})\end{array}$ \\
\hline 1 & 5 & 3.32 & 5 \\
$\mathbf{s y n t h e s i z e d ~ F M C u N P s}(\boldsymbol{\mu g} / \mathbf{m l})$ & 10 \\
3 & 10 & 6.75 & 15 \\
4 & 15 & 12.02 & 20 \\
\hline
\end{tabular}

Determination of reducing power assay of greenly synthesized FMCuNPs

The inhibitory concentration ( $\mathrm{IC}_{50}$ ) for the reducing power assay of greenly synthesized FMCuNPs (fig. 15 and table 2 ) is found to be $24.35 \mu \mathrm{g} / \mathrm{ml}$, comparable to Ascorbic acid, having $\mathrm{IC}_{50}$ value of $22.98 \mu \mathrm{g} / \mathrm{ml}$.

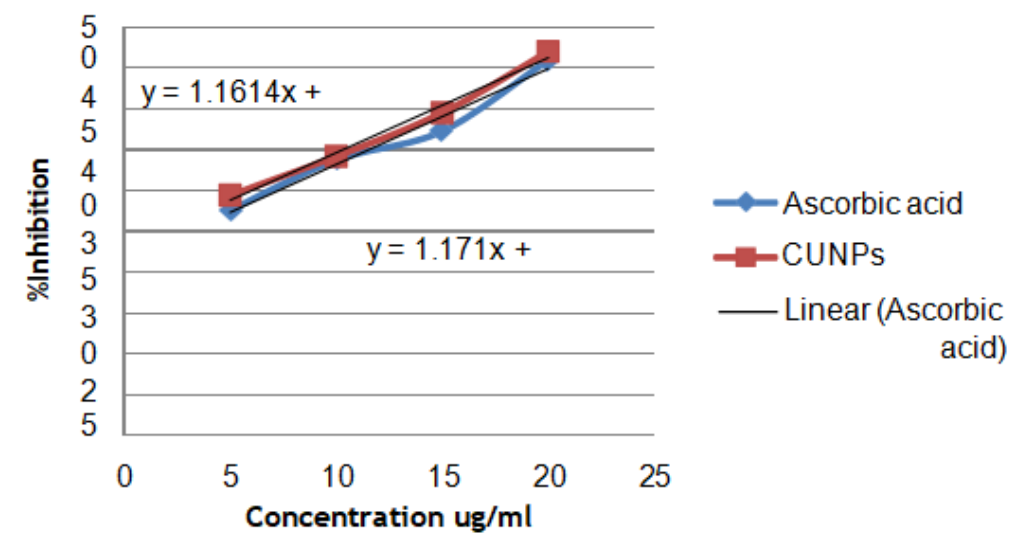

Fig. 15: Reducing power assay by ascorbic acid 
Table 2: Determination of reducing power assay of greenly synthesized FMCuNPs

\begin{tabular}{|c|c|c|c|c|}
\hline S. No. & $\begin{array}{l}\text { Concentration of } \\
\text { ascorbic acid }(\mu \mathrm{g} / \mathrm{ml})\end{array}$ & $\begin{array}{l}\text { Percentage inhibition of } \\
\text { ascorbic acid standard }(\mu \mathrm{g} / \mathrm{ml})\end{array}$ & $\begin{array}{l}\text { Concentration of greenly } \\
\text { synthesized FMCuNPs }(\mu \mathrm{g} / \mathrm{ml})\end{array}$ & $\begin{array}{l}\text { Percentage inhibition greenly } \\
\text { synthesized FMCuNPs }(\mu \mathrm{g} / \mathrm{ml})\end{array}$ \\
\hline 1 & 5 & 27.61 & 5 & 29.43 \\
\hline 2 & 10 & 33.74 & 10 & 34.21 \\
\hline 3 & 15 & 37.27 & 15 & 39.54 \\
\hline \multirow[t]{2}{*}{4} & 20 & 45.95 & 20 & 47.01 \\
\hline & $\mathrm{IC}_{50}$ & 22.98 & $\mathrm{IC}_{50}$ & 24.35 \\
\hline
\end{tabular}

\section{Determination of total antioxidant assay of greenly synthesized FMCuNPs}

Moreover, the designed nanomaterial was found to have significant antioxidant potential. The inhibitory concentration (IC 50 ) for the total antioxidant assay of green synthesized FMCuNPs (fig. 16 and table 3 ) is found to be $16.83 \mu \mathrm{g} / \mathrm{ml}$.

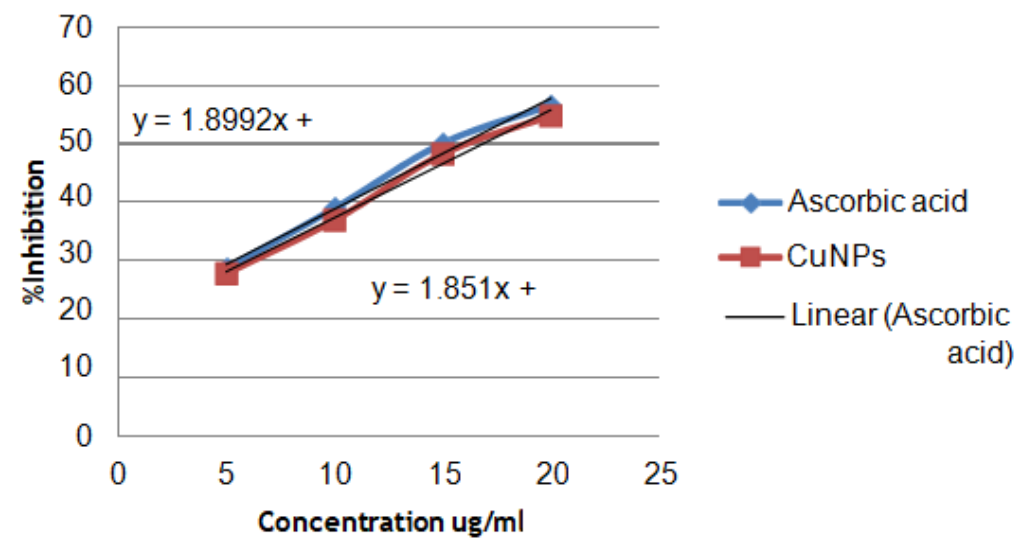

Fig. 16: Total anti-oxidant effect by ascorbic acid

Table 3: Determination of total antioxidant assay of greenly synthesized FMCuNPs

\begin{tabular}{lllll}
\hline $\begin{array}{l}\text { S. No. } \\
\end{array}$ & $\begin{array}{l}\text { Concentration of } \\
\text { ascorbic acid }(\boldsymbol{\mu g} / \mathbf{m l})\end{array}$ & $\begin{array}{l}\text { Percentage inhibition of } \\
\text { ascorbic acid standard }(\boldsymbol{\mu g} / \mathbf{m l})\end{array}$ & $\begin{array}{l}\text { Concentration of greenly } \\
\text { synthesized FMCuNPs }(\boldsymbol{\mu g} / \mathbf{m l})\end{array}$ & $\begin{array}{l}\text { Percentage inhibition greenly } \\
\text { synthesized FMCuNPs }(\boldsymbol{\mu g} / \mathbf{m l})\end{array}$ \\
\hline 1 & 5 & 28.67 & 5 & 27.81 \\
2 & 10 & 38.97 & 10 & 15 \\
3 & 15 & 50.11 & 20 & 48.31 \\
4 & 20 & 56.61 & $\mathrm{IC}_{50}$ & 54.87 \\
\hline
\end{tabular}

\section{In vitro anticancer activity}

\section{MTT assay of green synthesized FMCuNPs using liver cancer cell line (HepG2) and breast cancer (MCF-7) cell line}

Finally, to analyse the cytotoxic activity of the Green synthesized FMCuNPs, we performed MTT assay with two well-established cancerous cell line HepG2 and MCF-7. The greenly synthesized FMCuNPs had IC 50 values of $57.56 \mu \mathrm{g} / \mathrm{ml}$ for HepG2 cell line and $56.41 \mu \mathrm{g} / \mathrm{ml}$ for MCF-7 cell line (fig. 17 and table 4). The comparative study of morphology alteration of the cell line in response to the treatment with FMCuNPs is also depicted in fig. 18. Thus our data showed that FMCuNPs has exerted a promising and selective cytotoxic activity against both HepG2 and MCF-7 cell line. 

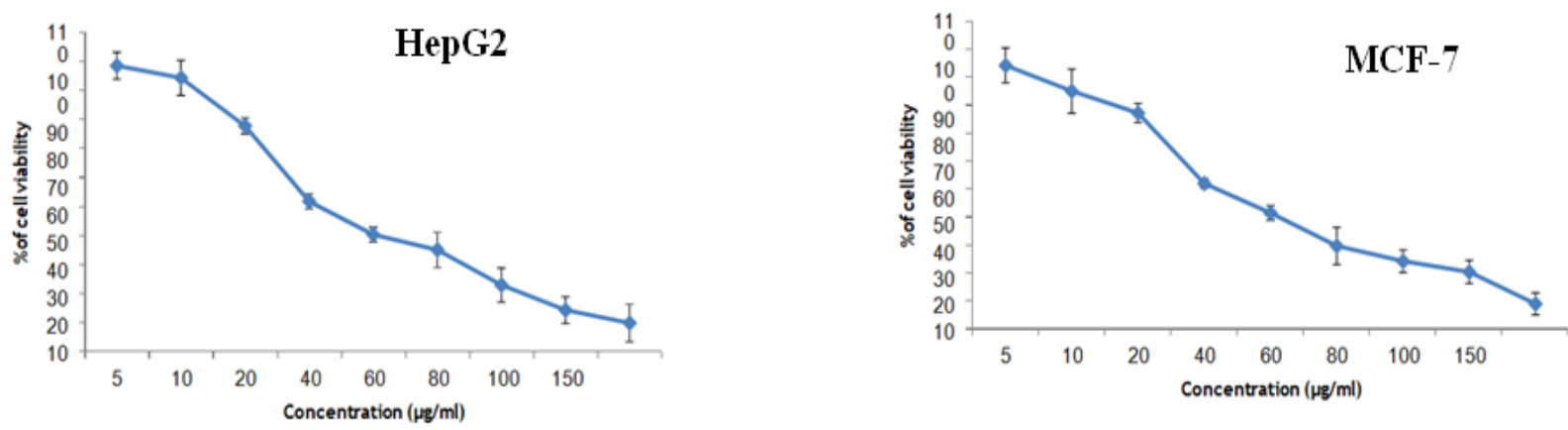

$\mathrm{n}=3$, mean \pm sd

Fig. 17: Cytotoxicity of FMCUNPs on HepG2 and MCF-7 cells

Table 4: Percentage inhibition of different concentrations of greenly synthesized FMCuNPs on HepG2 and MCF-7 Cells

\begin{tabular}{|c|c|c|c|c|}
\hline Compound & Cell line & Concentration $(\mu \mathrm{g} / \mathrm{ml})$ & \% Viability & $\mathrm{IC}_{50}(\mu \mathrm{g} / \mathrm{ml})$ \\
\hline Greenly & Liver Cancer Cell Line (HepG2 Cell) & 5 & 98.6524 & 57.56 \\
\hline Synthesized & & 10 & 94.4745 & \\
\hline \multirow[t]{16}{*}{ FMCuNPs } & & 20 & 77.8977 & \\
\hline & & 40 & 51.8869 & \\
\hline & & 60 & 40.4313 & \\
\hline & & 80 & 35.1752 & \\
\hline & & 100 & 23.0459 & \\
\hline & & 150 & 14.4205 & \\
\hline & & 200 & 9.9730 & \\
\hline & & 5 & 94.0298 & 56.41 \\
\hline & Breast cancer Cell line & 10 & 84.8258 & \\
\hline & (MCF-7 cell) & 20 & 76.9900 & \\
\hline & & 40 & 51.7412 & \\
\hline & & 60 & 41.1693 & \\
\hline & & 80 & 29.3532 & \\
\hline & & 100 & 23.8806 & \\
\hline & & 150 & 20.0248 & \\
\hline & & 200 & 8.5820 & \\
\hline
\end{tabular}




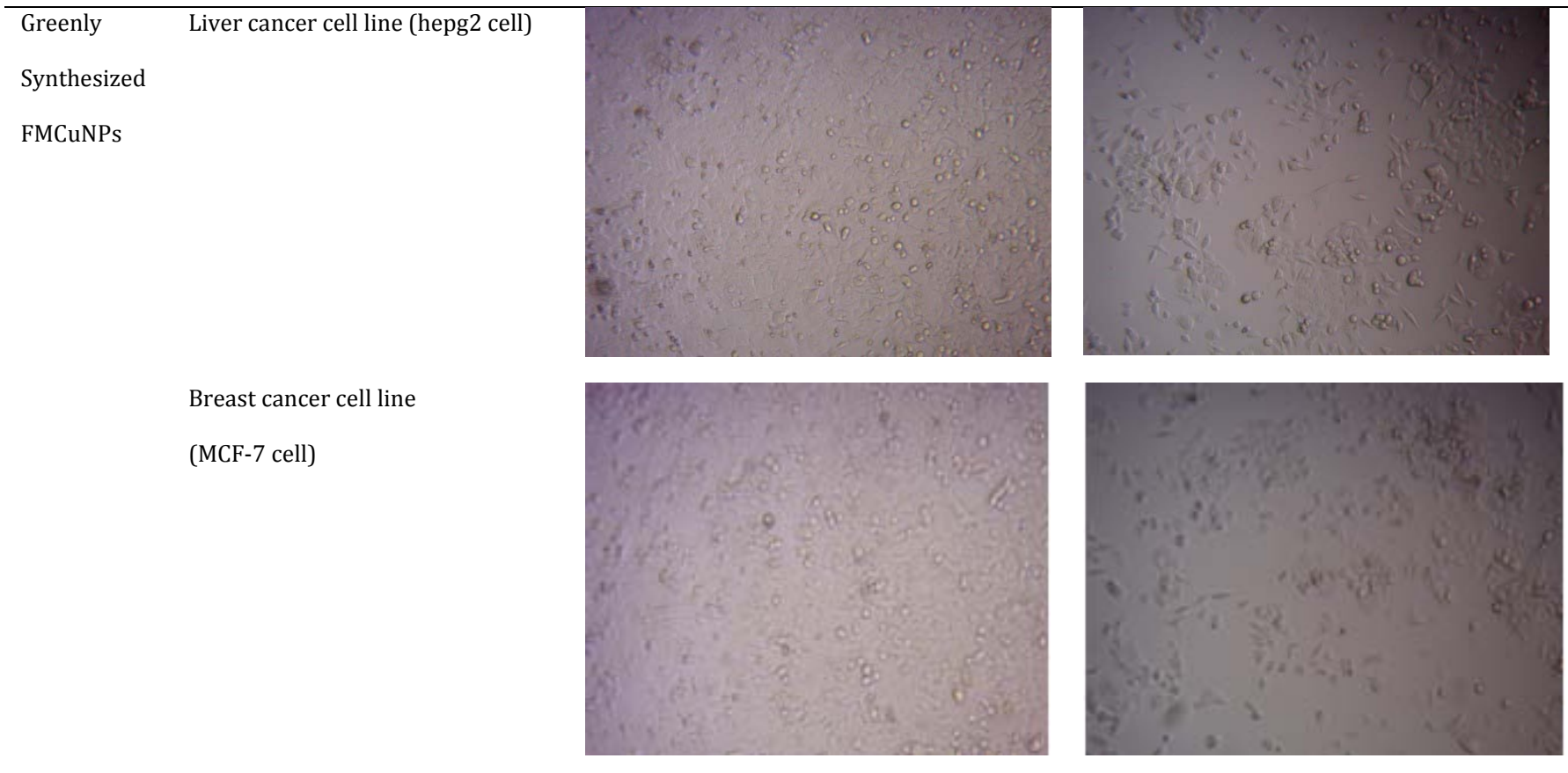

Fig. 18: Morphological changes in HepG2 and MCF-7 Cell lines

\section{In vivo anticancer activity of greenly synthesized FMCuNPs by using dalton's lymphoma ascites in mice}

Next, to validate our observation in in vivo model we have introduced cell line-induced mice cancer model in this study. Dalton's Lymphoma Ascites (1 X 106) was injected intraperitoneally to mice and the mice were kept for $7 \mathrm{~d}$ to allow the significant growth of tumour mass. Next, a group of these mice were treated with FMCuNPs intraperitoneally and a group were treated with fluorouracil and marked as the positive control. After completion of all the treatment, the mice were sacrificed; the blood was withdrawn from each mouse by retro-orbital plexus method and several clinical parameters like haematological parameter, serum enzyme and lipid profile etc were assayed.

\section{Effect on haematological parameters}

Analysis of haematological parameters reveals a significant decrease of RBC, Haemoglobin (Hb), platelets and a notable increase of WBC in the DLA control group compared to the normal control group (table 5). On the contrary, treatment with FMCuNPs at the dose of $200 \mathrm{mg} / \mathrm{kg}$ significantly increases the $\mathrm{Hb}$ content, $\mathrm{RBC}$, platelets with simultaneous reduction of the $\mathrm{WBC}$ count in comparison to DLA control group. Thus our data validates the anticancer potential of the FMCuNPs.

Table 5: Effect of FMCuNPs on hematological parameters

\begin{tabular}{llllll}
\hline Treatment & Total WBC cells $/ \mathbf{m l x 1 0}^{3}$ & RBC count mill $/ \mathbf{m m}^{3}$ & Hb Gm/dl & PCV \% & Platelets Lakhs/mm \\
\hline G1 & $9.95 \pm 1.28$ & $4.27 \pm 0.99$ & $12.40 \pm 2.42$ & $14.65 \pm 2.84$ & $3.20 \pm 0.78$ \\
G2 & $14.15 \pm 2.65^{\mathrm{a}^{* *}}$ & $2.32 \pm 0.48^{\mathrm{a}^{* *}}$ & $7.32 \pm 0.8$ & $31.45 \pm 3.55^{\mathrm{a}^{* *}}$ & $1.60 \pm 0.62^{\mathrm{*}^{* *}}$ \\
G3 & $11.35 \pm 1.92^{\mathrm{b}^{* *}}$ & $3.95 \pm 0.85^{\mathrm{b}^{* *}}$ & $11.4 \pm 1.80^{\mathrm{b}^{* *}}$ & $19.21 \pm 2.60^{\mathrm{b}^{* *}}$ & $2.67 \pm 0.54^{\mathrm{b}^{* *}}$ \\
G4 & $12.40 \pm 2.32^{\mathrm{b}^{*}}$ & $3.30 \pm 0.82^{\mathrm{b}^{*}}$ & $10.80 \pm 1.78^{\mathrm{b}^{*}}$ & $22.24 \pm 1.60^{\mathrm{b}^{*}}$ & $2.32 \pm 0.7 \mathrm{~b}^{\mathrm{b}^{*}}$ \\
\hline
\end{tabular}

G1-Normal Control, G2-Cancer Control, G3-Positive control, G4-Treatment control of FMCUNPs-Flavonoid Mediated Copper Nanoparticles, All values are expressed as mean \pm SEM for 6 animals in each group, ${ }^{* *}$ a-Values are significantly different from Normal control (G1) at P<0.001, ${ }^{*} b-$ Values are significantly different from cancer control (G2) at $\mathrm{P}<0.01,{ }^{*}$ b-Values are significantly different from cancer control (G2) at $\mathrm{P}<0.001$

\section{Effect on biochemical parameters}

The introduction of DLA cells results in a significant increase of the level of Total Cholesterol, Aspartate aminotransferase, Alanine aminotransferase, Alkaline phosphatase in the tumour control animals (G2), when compared to the normal group. Surprisingly, the treatment with FMCuNPs at the dose of $200 \mathrm{mg} / \mathrm{kg}$ body weight reversed these changes towards the normal level (table 6). The biochemical parameter of the FMCuNPs treated set is found to be comparable with that of the normal group. 
Table 6: Effect of FMCuNPs on serum enzymes and lipid proteins

\begin{tabular}{|c|c|c|c|c|c|}
\hline Treatment & Cholesterol (mg/dl) & TGL (mg/dl) & AST (U/l) & ALT (U/l) & $\operatorname{ALP}(U / \mathrm{l})$ \\
\hline $\mathrm{G}_{1}$ & $96.30 \pm 3.65$ & $125.4 \pm 4.50$ & $34.44 \pm 1.30$ & $32.40 \pm 1.32$ & $128.35 \pm 2.30$ \\
\hline $\mathrm{G}_{2}$ & $142.95 \pm 4.60^{\mathrm{a}^{* *}}$ & $204.45 \pm 6.40^{\mathrm{a}^{* *}}$ & $6.45 \pm 2.80^{\mathrm{a}^{* *}}$ & $56.20 \pm 2.25^{\mathrm{a}^{* *}}$ & $240.50 \pm 4.28^{\mathrm{a}^{* *}}$ \\
\hline $\mathrm{G}_{3}$ & $110.50 \pm 3.92^{\mathrm{b}^{* *}}$ & $150.55 \pm 3.80^{\mathrm{b}^{* *}}$ & $54.25 \pm 1.80^{\mathrm{b} * *}$ & $42.40 \pm 1.70^{\mathrm{b}^{* *}}$ & $165.30 \pm 2.40^{\mathrm{b}^{* *}}$ \\
\hline $\mathrm{G}_{4}$ & $122.30 \pm 2.55^{b^{*}}$ & $163.22 \pm 2.40^{\mathrm{b}^{*}}$ & $72.40 \pm 1.92^{b^{*}}$ & $45.50 \pm 1.25^{\mathrm{b}^{*}}$ & $188.65 \pm 2.65^{b^{*}}$ \\
\hline
\end{tabular}

G1-Normal Control, G2-Cancer Control, G3-Positive control, G4-Treatment control of FMCUNPs-Flavonoid Mediated Copper Nanoparticles, All values are expressed as mean \pm SEM for 6 animals in each group, ${ }^{* *}$ a-Values are significantly different from Normal control (G1) at P<0.001, ${ }^{*} b-$ Values are significantly different from cancer control (G2) at $\mathrm{P}<0.01,{ }^{* *} \mathrm{~b}-$ Values are significantly different from cancer control (G2) at $\mathrm{P}<0.001$

\section{Effect on tumour growth}

Next we asked whether FMCuNPs has any effect on the survival of animal having cancerous growth. In the DLA tumour control group, the average life span of animals was reduced to $50 \%$, whereas FMCuNPs at the dose of $200 \mathrm{mg} / \mathrm{kg}$ body weight increases the life span to $70 \%$ and $72 \%$, respectively. Thus our data reveals that the FMCuNPs has a considerable potential of augmentation of life span of animals having cancerous growth. The anti-tumor nature of FMCuNPs was further verified by the significant reduction in percent increase of body weight of animals treated with FMCuNPs at the dose of $200 \mathrm{mg} / \mathrm{kg}$ body weight when compared to DLA tumor-bearing mice. It was also supported by the significant reduction in packed cell volume and viable tumour cell count in both the extent of treatment when compared to the DLA tumour control (table 7).

Table 7: Effect of FMCuNPs on the life span, body weight and cancer cell count of tumor-induced mice

\begin{tabular}{|c|c|c|c|c|}
\hline Treatment & Number of animals & \% ILS life span & Increase in body weight grams & Cancer cell count $\mathrm{ml} \times \mathbf{1 0}^{6}$ \\
\hline $\mathrm{G}_{1}$ & 6 & $>30 \mathrm{~d}$ & $2.20 \pm 0.50$ & - \\
\hline $\mathrm{G}_{2}$ & 6 & $50 \%$ & $7.84 \pm 1.10^{\mathrm{a}^{* *}}$ & $2.60 \pm 0.32^{\mathrm{a}^{* *}}$ \\
\hline $\mathrm{G}_{3}$ & 6 & $92 \%$ & $3.72 \pm 0.55^{b^{* *}}$ & $1.39 \pm 0.31^{\mathrm{b}^{* *}}$ \\
\hline $\mathrm{G}_{4}$ & 6 & $72 \%$ & $6.13 \pm 0.90^{\mathrm{b}^{*}}$ & $1.98 \pm 0.40^{\mathrm{b}^{*}}$ \\
\hline
\end{tabular}

G1-Normal Control, G2-Cancer Control, G3-Positive control, G4-Treatment control of FMCUNPs-Flavonoid Mediated Copper Nanoparticles, All values are expressed as mean \pm SEM for 6 animals in each group, ${ }^{* *}$ a-Values are significantly different from Normal control (G1) at P<0.001, ${ }^{*}$ bValues are significantly different from cancer control (G2) at $\mathrm{P}<0.01,{ }^{* *} \mathrm{~b}-$ Values are significantly different from cancer control (G2) at $\mathrm{P}<0.001$

Viable cell count (fig. 19)

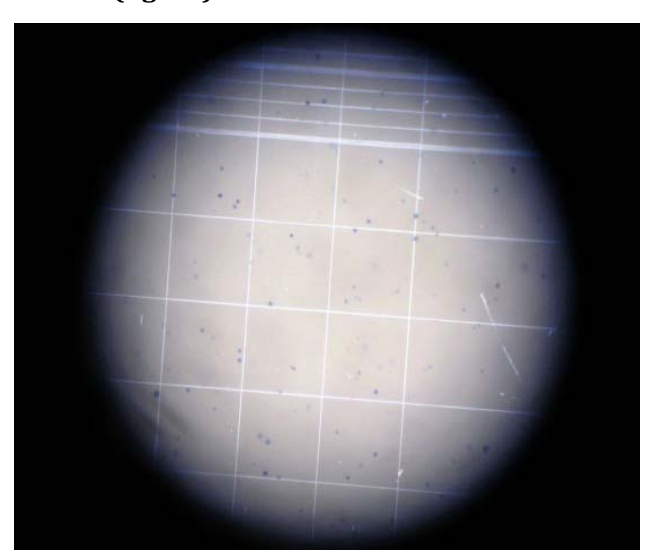

Normal control

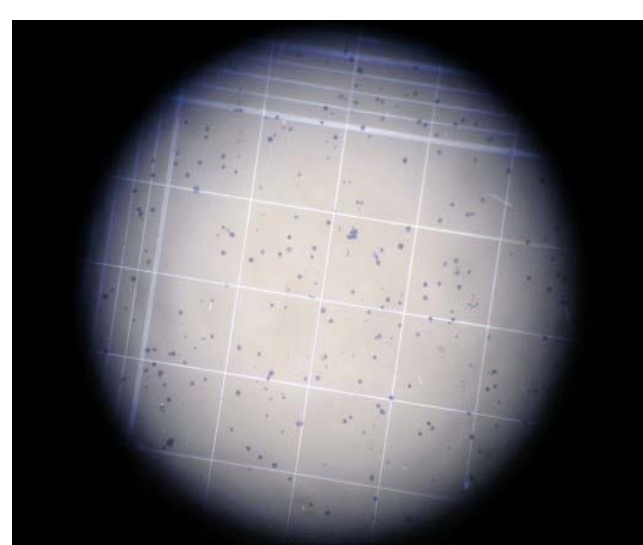

Cancer control 


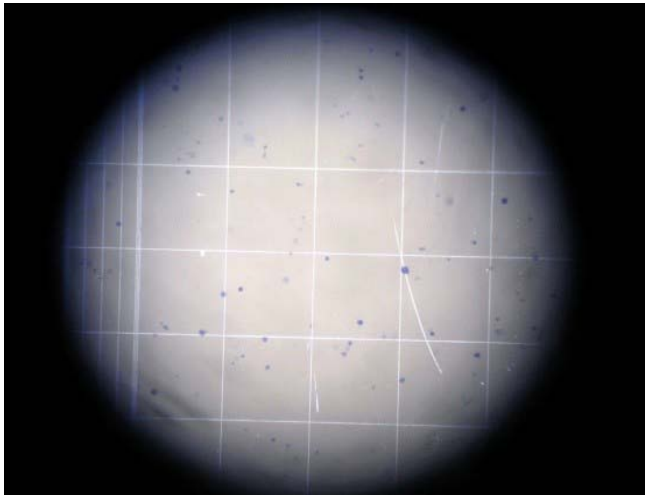

Positive control

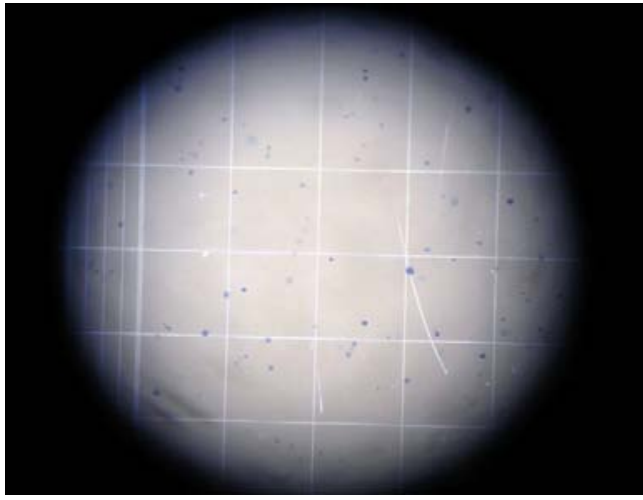

Treatment control-FMCuNPs

Fig. 19: Viable cell count of in vivo anticancer activity of FMCuNPs

Histopathological results (Animal liver) (fig. 20)

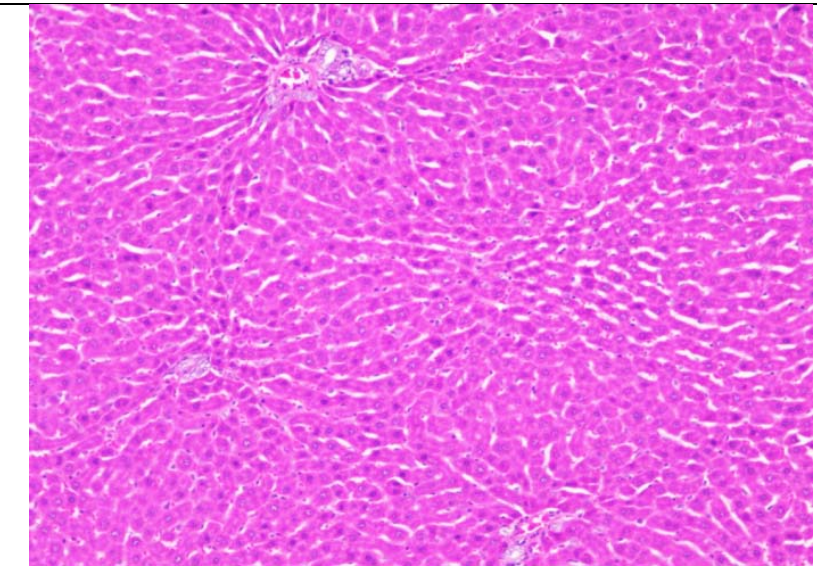

Normal control

Section show structure of liver with sheets of hepatocytes separated by sinusoids cartial vein and portal tract appear normal

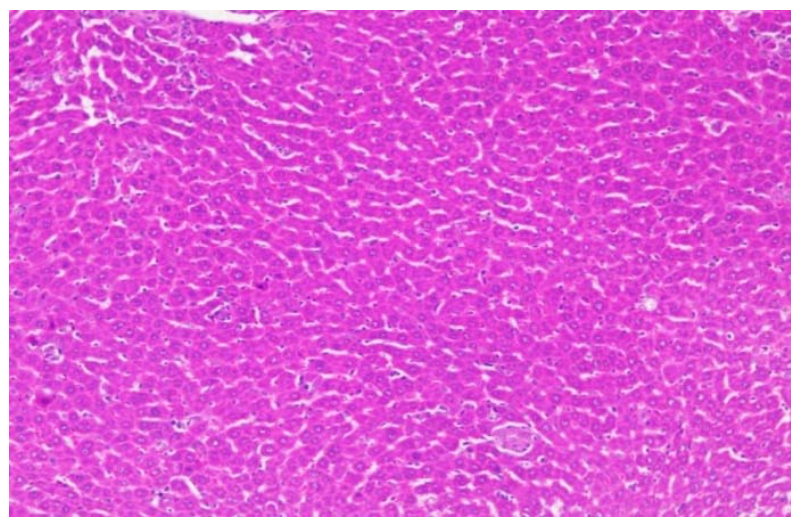

Positive control

Section show structure of liver presented mild hepatic congestion at sinusoids and the portal vessel, pericentre globular micro-steatosis, no kuffe cell proliferation, mild hepatocyte diffuse necrosis and mononuclear infiltrate.

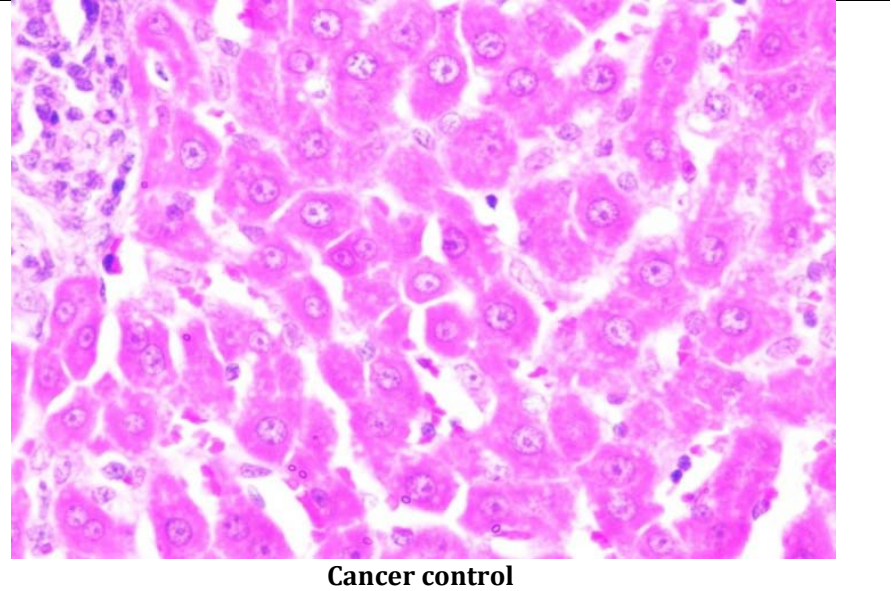

Section shows the structure of liver presented hepatic congestion at sinusoids and the portal vessel, pericentre globular micro-steatosis, kuffe cell proliferation, diffuse hepatocyte necrosis and mononuclear infiltrate

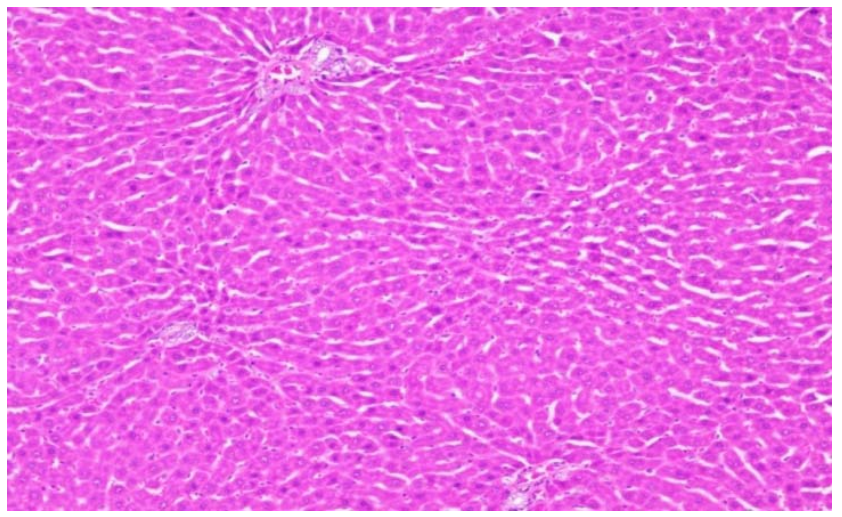

Treatment control-FMCuNPs

Section show structure of liver presented moderate hepatic congestion at sinusoids and the portal vessel, pericentre globular micro-steatosis, less kuffe cell proliferation, mild hepatocyte diffuse necrosis and mononuclear infiltrate.

Fig. 20: Histopathological images of the animal liver in vivo anticancer activity of FMCuNPs 


\section{DISCUSSION}

Cancer is one of the principal causes of global morbidity and mortality. Amongst the non-infectious diseases, cancer holds the second position just after cardiovascular disease in terms of the leading cause of worldwide death. One in eight people dies due to cancer globally. The death rate due to cancer is even more than the cumulative death rate of AIDS, tuberculosis, and malaria together.

Thus globally, scientists are involved in relentless research in order to overpower cancer in the constant battle through the development in cures and preventative therapies. Cancer is typically characterized by the continual proliferation of cells in an uncontrolled manner with concomitant formation of tumour mass. In the malignant condition, few cells from the primary tumour migrate to a distant loci and form secondary cancer. Chemotherapy, radiotherapy and chemically derived drugs are most popular anticancer treatment. But unfortunately, this therapeutic measure suffers from undesirable side effects issues. Thus, a continuous hunt is going on globally to establish alternative treatments and therapies against cancer.

From ancient time, herbal medicines are considered as a very effective therapeutic approach in the Asian sub-continent. Many literature reports are also there explaining the therapeutic potential of plant-based products in the anti-cancer treatment. Quercetin is also reported to be effective against cancer [43].

Moreover, to enhance the efficacy, bioavailability, dose-response, targeting ability herbal medicines are often administered in the form of nanoparticles. In this manuscript, we have reported the green synthesis schemes of Cu-based nano particle from Quercetin isolated from aqueous extract of Thespesia populnea. Next, through UV-Visible Spectroscopy, FT-IR, Atomic Absorption Spectroscopy and SEM, EDAX, XRD, Zeta Potential, Particle Size Analysis we have confirmed the synthesis of the nanoparticle. Pharmacological evaluation of Quercetin-mediated copper nanoparticles confirms its anti-oxidant, anti-cancer activity.

Comparative analysis reveals that copper nanoparticles of quercetin is a better anti-oxidant and anti-cancer agent than isolated free Quercetin as confirmed by the $\mathrm{IC}_{50}$ values. Furthermore, the present investigation was carried out to evaluate the anti-tumour activity of FMCuNPs in DLA tumour-bearing mice. The FMCuNPs significantly inhibited the tumour volume, packed cell volume, tumour (viable) cell count and reverse the haematological parameters to more or less normal levels. Treatment with FMCuNPs elicited the Haemoglobin (Hb) content and RBC with concomitant downregulation of WBC counts more or less to normal levels significantly.

Finally, the extension of the lifespan of animals confirms the efficacy of the anti-cancer potential of the CuNPs [19]. Usually, in cancer chemotherapy, myelosuppression and anaemia are the associated major problems $[20,21]$. The anaemia encountered in tumour-bearing mice is mainly due to reduction in RBC or Haemoglobin percentage [22]. But here, we have reported that FMCuNPs possess a protective action on the haemopoietic system apart from being a potent anti-cancer agent. Moreover, it is reported that the presence of tumour in the human body or in experimental animals affect several metabolic functions of the liver. The elevated level of total cholesterol, TG, AST, ALT, ALP in serum of tumour inoculated animals indicated liver damage and loss of functional integrity of cell membrane. In the present study also, the biochemical estimation of DLA inoculated animals exhibited marked changes indicating the toxic effect of the tumour. On the contrary, the FMCuNPs induced reversal of these biochemical parameters confirms its overall anti-cancerous and hepatoprotective activity.

\section{ACKNOWLEDGEMENT}

I thank all the following individuals for their expertise and assistance throughout all aspects of our study and for their help in writing the manuscript.

Dr. D Stephen, M. Sc., Ph. D., Department of Botany, American College, Madurai for plant authentication. Dr. N. Chidambaranathan, M. Pharm., Ph. D., Department of Pharmacology, K M College of Pharmacy, Uthangudi, Madurai for In vivo Anti-cancer activity. Dr. S Lakshmana Prabu, M. Pharm., Ph. D., and Mr. Selvakumar, Anna University, Trichy for Particle size and Zeta potential analysis. Dr. Saravanan, Director, Instrumentation Centre, Ayya Nadar Janaki Ammal College, Sivakasi for Atomic Absorption Spectroscopy. Mr. M. Muthu, Department Of Chemistry, Madurai Kamaraj University, Madurai for NMR analysis. MR. V Krishna Prabhu, Technician, International Research Centre, Mr. Selvakumar, Kalasalingam Academy of Research and Education, Krishnakoil for FT-IR, XRD, SEM analysis. Dr. P Arulselvan, M. Sc., Ph. D., Managing Director, Scigen Research and Innovation Private Limited, Thanjavur for In vitro Anti-cancer activity.

\section{CONCLUSION}

Naturally, charged copper ion itself possesses a mild anti-cancer agent besides having a considerable toxic side effect. Conversion of charged species to the neutral copper or its nanoparticles is reported to augment its activity with minimising the side effects. The reduction of charged Copper ion to neutral form by chemical method involves the use of several chemical agents and also is associated with side reaction leading to the production of toxic side products. But natural product mediated reduction process of Copper ion resulting in the formation of neutral Copper atom or Copper nanoparticles can avoid the formation of undesired bi-products. In this study isolated flavonoid (natural product) used to reduce and stabilize the Copper Sulphate into Copper nanoparticles. It is environmental friendly and nontoxic method for synthesis of copper nanoparticles. In future development of Copper nanoparticles, green chemistry based synthesis is suitable for non toxic formulation and cancer target delivery.

\section{FUNDING}

Nil

\section{AUTHORS CONTRIBUTIONS}

All the authors have contributed equally.

\section{CONFLICT OF INTERESTS}

\section{Declared none}

\section{REFERENCES}

1. Appenzeller T. The man who dared to think small. Science. 1991;254(5036):1300. doi: 10.1126/science.254.5036.1300. PMID 17773595.

2. Murray CB, Kagan CR, Bawendi MG. Synthesis and characterization of monodisperse nanocrystals and close-packed nanocrystal assemblies. Annu Rev Mater Sci. 2000;30(1):545-610. doi: 10.1146/annurev.matsci.30.1.545.

3. Mazzola L. Commercializing nanotechnology. Nat Biotechnol. 2003;21(10):1137-43. doi: 10.1038/nbt1003-1137, PMID 14520392.

4. Paull R, Wolfe J, Hebert P, Sinkula M. Investing in nanotechnology. Nat Biotechnol. 2003;21(10):1144-7. doi: 10.1038/nbt1003-1144, PMID 14520393. 
5. Taton TA. Nanostructures as tailored biological probes. Trends Biotechnol. 2002;20(7):277-9. doi: 10.1016/s0167-7799(02)01973-x, PMID 12062965.

6. Whitesides GM. The 'right' size in nanobiotechnology. Nat Biotechnol. 2003;21(10):1161-5. doi: 10.1038/nbt872, PMID 14520400.

7. Govil JN. Current concepts of multidiscipline approach to the medicinal plants govil n. glimpses in plant research. Part J. $1998 ; X I I: 244$.

8. Chandran SP, Chaudhary M, Pasricha R, Ahmad A, Sastry M. Synthesis of gold Nano triangles and silver nanoparticles using Aloe vera plant extract. Biotechnol Prog. 2006;22(2):577-83. doi: 10.1021/bp0501423, PMID 16599579.

9. Allen JM, Xu J, Blahove M, Canonico-May SA, Santaloci TJ, Braselton ME, Stone JW. Synthesis of less toxic gold Nano rods by using dodecyl ethyl dimethylammonium bromide as an alternative growth-directing surfactant. J Colloid Interface Sci. 2017;505:1172-6. doi: 10.1016/j.jcis.2017.06.101, PMID 28715861.

10. Biao L, Tan S, Wang Y, Guo X, Fu Y, Xu F, Zu Y, Liu Z. Synthesis, characterization and antibacterial study on the chitosan-functionalized Ag nanoparticles. Mater Sci Eng C Mater Biol Appl. 2017;76:73-80. doi: 10.1016/j.msec.2017.02.154, PMID 28482584.

11. Sathishkumar P, Preethi J, Vijayan R, Mohd Yusoff AR, Ameen F, Suresh S, Balagurunathan R, Palvannan T. Anti-acne, anti-dandruff and antibreast cancer efficacy of green synthesised silver nanoparticles using coriandrum sativum leaf extract. J Photochem Photobiol B. 2016;163:6976. doi: 10.1016/j.jphotobiol.2016.08.005, PMID 27541567.

12. Venil CK, Sathishkumar P, Malathi M, Usha R, Jayakumar R, Yusoff ARM, Ahmad WA. Synthesis of flexirubin-mediated silver nanoparticles using Chryseobacterium artocarpi CECT 8497 and investigation of its anticancer activity. Mater Sci Eng C Mater Biol Appl. 2016;59:228-34. doi: 10.1016/j.msec.2015.10.019, PMID 26652368.

13. Kuppusamy P, Yusoff MM, Maniam GP, Govindan N. Biosynthesis of metallic nanoparticles using plant derivatives and their new avenues in pharmacological applications- An updated report. Saudi Pharm J. 2016;24(4):473-84. doi: 10.1016/j.jsps.2014.11.013, PMID 27330378.

14. Rehana D, Mahendiran D, Kumar RS, Rahiman AK. In vitro antioxidant and antidiabetic activities of zinc oxide nanoparticles synthesized using different plant extracts. Bioprocess Biosyst Eng. 2017;40(6):943-57. doi: 10.1007/s00449-017-1758-2, PMID 28361361.

15. Reddy NJ, Nagoor Vali DN, Rani M, Rani SS. Evaluation of antioxidant, antibacterial and cytotoxic effects of green synthesized silver nanoparticles by Piper longum fruit. Mater Sci Eng C Mater Biol Appl. 2014;34:115-22. doi: 10.1016/j.msec.2013.08.039, PMID 24268240.

16. Ahmad B, Hafeez N, Bashir S, Rauf A, Mujeeb-Ur-Rehman M. Phytofabricated gold nanoparticles and their biomedical applications. Biomed Pharmacother. 2017;89:414-25. doi: 10.1016/j.biopha.2017.02.058, PMID 28249242.

17. Ovais M, Raza A, Naz S, Islam NU, Khalil AT, Ali S, Khan MA, Shinwari ZK. Current state and prospects of the phytosynthesized colloidal gold nanoparticles and their applications in cancer theranostics. Appl Microbiol Biotechnol. 2017;101(9):3551-65. doi: 10.1007/s00253-017-82504, PMID 28382454.

18. Jayaprakash N, Vijaya JJ, Kaviyarasu K, Kombaiah K, Kennedy LJ, Ramalingam RJ, Munusamy MA, Al-Lohedan HA. Green synthesis of Ag nanoparticles using Tamarind fruit extract for the antibacterial studies. J Photochem Photobiol B. 2017;169:178-85. doi: 10.1016/j.jphotobiol.2017.03.013, PMID 28347958.

19. Khodadadi B, Bordbar M, Nasrollahzadeh M. Green synthesis of Pd nanoparticles at apricot kernel shell substrate using Salvia hydrangea extract: catalytic activity for reduction of organic dyes. J Colloid Interface Sci. 2017;490:1-10. doi: 10.1016/j.jcis.2016.11.032, PMID 27870949.

20. Sathishkumar P, Vennila K, Jayakumar R, Yusoff AR, Hadibarata T, Palvannan T. Phyto-synthesis of silver nanoparticles using Alternanthera tenella leaf extract: an effective inhibitor for the migration of human breast adenocarcinoma (MCF-7) cells. Bioprocess Biosyst Eng. 2016;39(4):651-9. doi: 10.1007/s00449-016-1546-4, PMID 26801668.

21. Heymach J, Krilov L, Alberg A, Baxter N, Chang SM, Corcoran RB, Dale W, DeMichele A, Magid Diefenbach CSM, Dreicer R, Epstein AS, Gillison ML, Graham DL, Jones J, Ko AH, Lopez AM, Maki RG, Rodriguez-Galindo C, Schilsky RL, Sznol M, Westin SN, Burstein H. Clinical cancer advances 2018: annual report on progress against cancer from the American Society of Clinical Oncology. J Clin Oncol. 2018;36(10):1020-44. doi: 10.1200/JCO.2017.77.0446, PMID 29380678.

22. Gabriel J, Chapter I. What is cancer? In: Gabriel J. The Biology of Cancer. 2nd ed. John Wiley \& Sons Ltd; 2007. p. 3-9.

23. Singh DK, Lippman SM. Cancer chemoprevention. Part 1: Retinoids and carotenoids and other classic antioxidants. Oncology (Williston Park). 1998;12(11):1643-53, 1657. PMID 9834941.

24. Hussain M, Raja NI, Iqbal M, Aslam S. Applications of plant flavonoids in the green synthesis of colloidal silver nanoparticles and impacts on human health. Iran J Sci Technol Trans Sci. 2019;43(3):1381-92. doi: 10.1007/s40995-017-0431-6.

25. Tagirova MA, Vasina SM. Study an application possibility of the flavonoids for the synthesis of copper nanoparticles. Int J Eng Sci Res Technol. 2015;4(4):78-81.

26. Radhakrishnan K, Rettinaraja T, Mohan A, Jainulabideen SS. Synthesis of silver nanoparticles using flavonoid: apigenin and its antibacterial effect. EJPMR. 2017;4(1):422-6.

27. Dhas NA, Raj CP, Gedanken A. Synthesis, characterization, and properties of metallic copper nanoparticles. Chem Mater. 1998;10(5):1446-52. doi: $10.1021 / \mathrm{cm} 9708269$.

28. Joshi SS, Patil SF, Iyer V, Mahumuni S. Radiation induced synthesis and characterization of copper nanoparticles. Nanostruct Mater. 1998;10(7):1135-44. doi: 10.1016/S0965-9773(98)00153-6.

29. Jana NR, Wang ZL, Sau TK, Pal T. Seed-mediated growth method to prepare cubic copper Nano particles. Curr Sci. 2000;79:1367-70.

30. Choi H, Park SH. Seedless growth of free-standing copper nanowires by chemical vapor deposition. J Am Chem Soc. 2004;126(20):6248-9. doi: 10.1021/ja049217+, PMID 15149219.

31. Guo Z, Liang X, Pereira T, Scaffaro R, Thomas Hahn HT. CuO nanoparticle filled vinyl-ester resin nanocomposites: fabrication, characterization and property analysis. Compos Sci Technol. 2007;67(10):2036-44. doi: 10.1016/j.compscitech.2006.11.017.

32. Gfeller D, Grosdidier A, Wirth M, Daina A, Michielin O, Zoete V. Swiss target prediction: a web server for target prediction of bioactive small molecules. Nucleic Acids Res. 2014;42(Web Server issue):W32-8. doi: 10.1093/nar/gku293, PMID 24792161.

33. Rana MG, Katbamna RV, Padhya AA, Dudhrejiya AD, Jivani NP, Sheth NR. In vitro anti-oxidant and free radical scavenging studies of alcoholic extract of Medicago sativa L. Rom. J Biol Plant Biol. 1996;55(1):15-22.

34. Pise NM, Jena KB, Maharana D, Sabale AB, Jagtap TG. Free radical scavenging, reducing power and biochemical composition of porphyra species. J Algal Biomass Utln. 2010;1(2):60-73.

35. Gupta M, Mazumder UK, Kumar RS, Sivakumar T, Vamsi MLM. Antitumor activity and antioxidant status of Caesalpinia bonducella against Ehrlich ascites carcinoma in Swiss albino mice. J Pharmacol Sci. 2004;94(2):177-84. doi: 10.1254/jphs.94.177, PMID 14978356.

36. Jaya Seema D, Saifullah B, Selvanayagam M, Gothai S, Hussein M, Subbiah S, Mohd Esa N, Arulselvan P. Designing of the anticancer nanocomposite with sustained release properties by using graphene oxide nanocarrier with phenethyl isothiocyanate as anticancer agent. Pharmaceutics. 2018;10(3):109. doi: 10.3390/pharmaceutics10030109.

37. Christina AJ, Joseph DG, Packialakshmi M, Kothai R, Robert SJ, Chidambaranathan N, Ramasamy M. Anticarcinogenic activity of withania somnifera dunal against dalton's ascitic lymphoma. J Ethnopharmacol. 2004;93(2-3):359-61. doi: 10.1016/j.jep.2004.04.004, PMID 15234777.

38. Unnikrishnan MC, Kuttan R. Tumour reducing and anticarcinogenic activity of selected spices. Cancer Lett. 1990;51(1):85-9. doi: 10.1016/0304-3835(90)90235-P. 
39. Agarwal RC, Rachana Jain R, Wasim Raju W, Ovais M. Anti carcinogenic effects of solanum lycopersicum fruit extract on swiss albino and C57B1 mice. Asian Pacific J Cancer Prev. 2009;10:379-82.

40. Beczerra DP, Castro FO, Alves APNN, DPessoa C, Moraes MO, Silveriira ER, Lima MAS, Elmiro FJM, Costa Lotufo LV. In vivo growth-inhibition of sarcoma 180 by piplartine and piperine, two alkaloid amides from Piper. Brazilian Journal of Medical and Biological Research. 2006;39(6):8017. doi: 10.1590/s0100-879x2006000600014, PMID 16751987.

41. Chitra V, Sharma S, Kayande N. Evaluation of anticancer activity of vitex negundo study in experimental animals: In vitro and in vivo study. International Journal of PharmTech Research. 2009;1(4):1485-9.

42. Dongre SH, Badami S, Natesan S, H RC. Antitumor activity of the methanol extract of hypericum hookerianum stem against ehrlich ascites carcinoma in swiss albino mice. J Pharmacol Sci. 2007;103(4):354-9. doi: 10.1254/jphs.FP0061088.

43. Jeong JH, An JY, Kwon YT, Rhee JG, Lee YJ. Effects of low dose quercetin: cancer cell-specific inhibition of cell cycle progression. J Cell Biochem. 2009;106(1):73-82. doi: 10.1002/jcb.21977, PMID 19009557. 